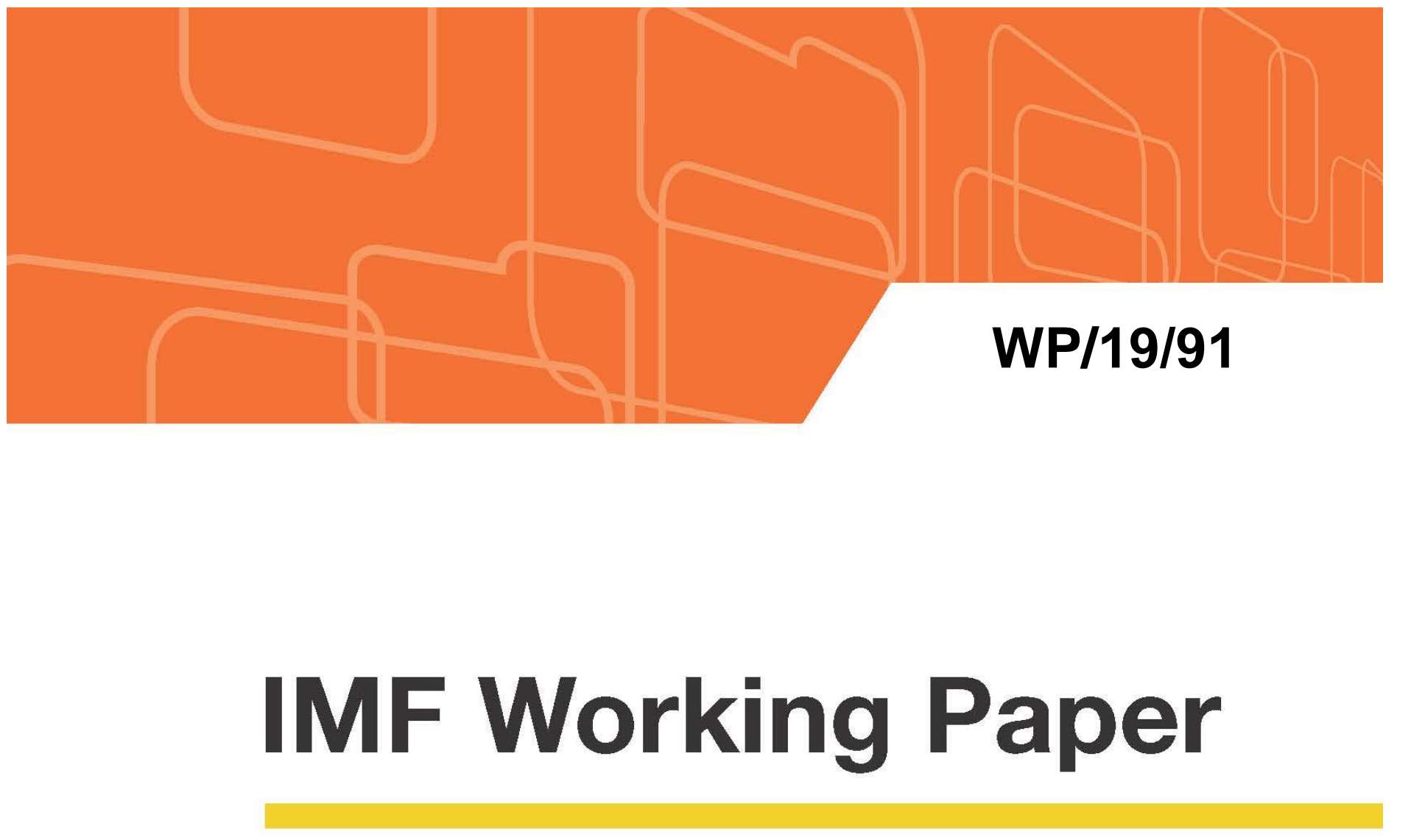

\title{
Is Technology Widening the Gender Gap? Automation and the Future of Female Employment
}

by Mariya Brussevich, Era Dabla-Norris, and Salma Khalid 


\title{
IMF Working Paper
}

Fiscal Affairs Department

\begin{abstract}
Is Technology Widening the Gender Gap? Automation and the Future of Female Employment Prepared by Mariya Brussevich, Era Dabla-Norris, Salma Khalid*
\end{abstract}

Authorized for distribution by Era Dabla-Norris

May 2019

IMF Working Papers describe research in progress by the author(s) and are published to elicit comments and to encourage debate. The views expressed in IMF Working Papers are those of the author(s) and do not necessarily represent the views of the IMF, its Executive Board, or IMF management.

\begin{abstract}
Using individual level data on task composition at work for 30 advanced and emerging economies, we find that women, on average, perform more routine tasks than men-tasks that are more prone to automation. To quantify the impact on jobs, we relate data on task composition at work to occupation level estimates of probability of automation, controlling for a rich set of individual characteristics (e.g., education, age, literacy and numeracy skills). Our results indicate that female workers are at a significantly higher risk for displacement by automation than male workers, with 11 percent of the female workforce at high risk of being automated given the current state of technology, albeit with significant cross-country heterogeneity. The probability of automation is lower for younger cohorts of women, and for those in managerial positions.
\end{abstract}

JEL Classification Numbers: E24, J16, J23, J24, O33

Keywords: Automation, Technological Change, Jobs, Female Labor Force, Occupational Choice, Gender Equality

Author's E-Mail Address: mbrussevich@imf.org, edablanorris@imf.org, skhalid@imf.org

\footnotetext{
* We would like to thank Kalpana Kochhar and Christine Kamunge for their useful suggestions and inputs, and seminar participants at the IMF, the IFC, and the Bank of Italy for their comments.
} 
ABSTRACT ___________________________________________________ 2

I. INTRODUCTION ______________________________________________________ 4

II. MEASURING EXPOSURE TO ROUTINIZATION: THE RTI INDEX_______ 7

A. Measuring Routineness ___________________________________________ 7

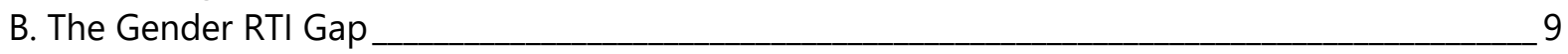

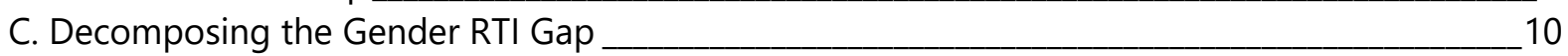

III. RISK OF AUTOMATION AND THE FUTURE OF WORK FOR WOMEN _________ 13

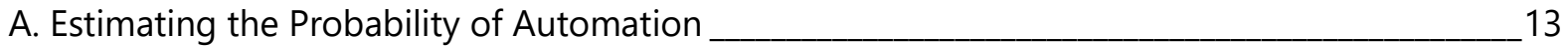

B. Gender Differences in Probability of Automation___________________________________

IV. NARROWING GENDER GAPS ACROSS GENERATIONS _____________________________

V. CONCLUSION______________________________________________________ 24

\section{FIGURES}

1. Relationship Between Female Labor Force Participation and Size of Manufacturing Sector

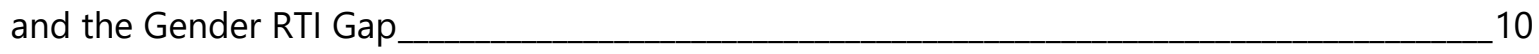

2. Gender Differences in RTI by Occupation___________________________________________________

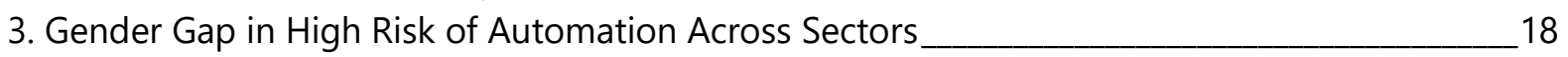

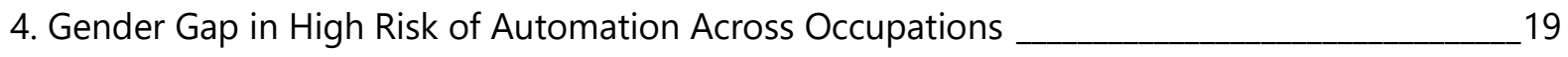

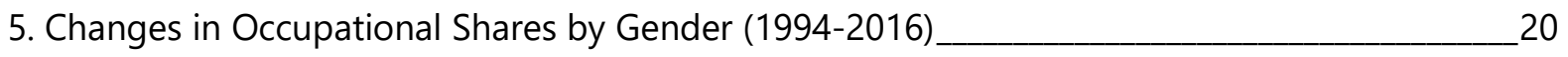

6. Gender Gaps in High Risk of Automation by Generation and Educational Level_______ 21

\section{TABLES}

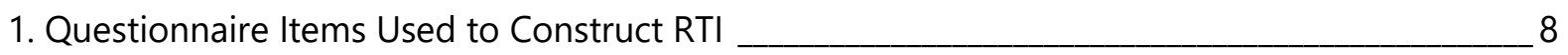

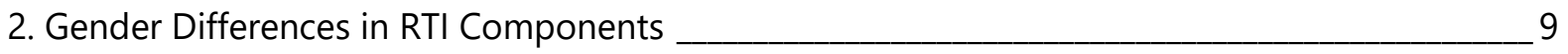

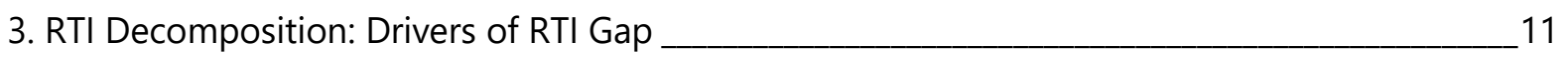

4. Gender Differences in Probability of Automation and SML_______________________________

5. Correlation of RTI Components and Probability of Automation ____________________________

6. Gender Gaps in High Risk of Automation by Generation and Occupation________________ 22

7. Gender Gaps in High Risk of Automation by Generation and Sector ________________________

\section{APPENDICES}

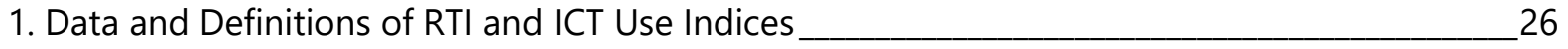

2. Additional Tables___________________________________________________________________ 


\section{INTRODUCTION}

There is growing policy concern about the implications of digitalization, artificial intelligence, and machine-learning for job displacement. Many jobs involving low- and middle-skill routine tasks are already being eliminated through labor-saving automation. Automation is hardly a novel phenomenon; traditional sectors such as agriculture and manufacturing have experienced large substitutions of labor with machine capital in the past. But computerization of white-collar services in advanced economies has accelerated in recent years (Acemoglu and Restrepo, 2018). At the same time, progress in machine learning is further expanding the set of activities that can be performed more efficiently by computers than humans (Brynjolfsson, Mitchell, and Rock, 2018), suggesting a significantly broader scope for task automation over the medium-term. What are the gender implications of this changing nature of work? How vulnerable are women's jobs to risk of displacement by technology? What are the intergenerational implications of automation?

This paper uses a task-based approach to investigate the exposure to automation, focusing on gender differences in labor market outcomes. We use individual-level data on task composition at work from the OECD's Programme for the International Assessment of Adult Competencies (PIAAC) for 30 advanced and emerging economies to identify threats and opportunities from technological progress for workers across sectors, occupations, and countries. Following the seminal task-based framework of Autor, Levy, and Murnane (2003), we first document the relative exposure of men and women to routine, abstract/analytical, and manual tasks.

Second, to quantify the potential impact on labor demand, we derive the likelihood of automation for male and female workers using detailed information on worker characteristics and task composition at work. We derive probabilities of automation at the individual level based on worker characteristics, including age, education, gender, literacy and numeracy skills, and a broad subset of task characteristics included in the PIAAC data set. This allows us to evaluate differences in the probability of automation across different demographic groups unlike most of the existing literature that distinguishes workers only by occupation. Specifically, we estimate the proportion of the female working population that is at risk of being displaced by automation given the current state of technology. Our individual-level estimates of probabilities of automatability also allow for a more detailed assessment of gender gaps across sectors, occupations, and age groups.

We find that women, on average, perform more routine or codifiable tasks than men across all sectors and occupations - tasks that are more prone to automation. Moreover, women perform fewer tasks requiring analytical input or abstract thinking (e.g., information-processing skills), where technological change can be complementary to human skills and improve labor productivity. Self-selection by women into specific occupations explains most of these differences, but women's exposure to routine job tasks varies significantly across countries. Within Europe, women in Eastern and Southern Europe perform more routine tasks than men, while the gender routineness gap (the difference in the routineness index values for women and 
men) is lowest in Scandinavian and Central European countries. For our sample as a whole, the gender routineness gap is highest in Japan, the Slovak Republic, Singapore, and Estonia.

Our results indicate that, given the current state of technology, 54 million male and female workers in 30 countries (28 OECD member countries, Cyprus, and Singapore) are at a high risk of being displaced by technology (i.e., facing higher than 70 percent likelihood of being automated) within the next two decades. ${ }^{1} \mathrm{~A}$ larger proportion of the female workforce is at a high risk for automation than the male workforce (11 percent versus 9 percent across the entire sample of countries), with 26 million female jobs potentially at stake in these countries. However, differences in proportions of women at high risk of automation vary substantially across countries-in Japan, for instance, women are three times more likely than men to fall into a highrisk group. Less well-educated and older female workers (aged 40 and older), and those in clerical, service, and sales positions are disproportionately exposed to automation.

There are some positive trends. Since the 1990 s, shifts in the labor force away from clerical and elementary occupations towards service sector and professional jobs has been more pronounced for women than men in our sample. This suggests that women are increasingly selecting into jobs that are more insulated from displacement by technology. A cross-sectional analysis of age cohorts shows that aggregate gender gaps are primarily driven by older cohorts of women. Gender automation gaps between men and women are smaller for younger cohorts even among workers facing the highest risk of automation (e.g., less-well educated, in clerical and sales positions). ${ }^{2}$

Our paper is related to several strands of literature. First, our paper is related to studies that use US-based routineness estimates at the occupational-level, to show that routine jobs are more susceptible to substitution of labor with information and communication technology (ICT) (Autor, Levy, and Murnane 2003; Goos, Manning, and Salomons, 2014; Das and Hilgenstock, 2018). ${ }^{3}$ Conversely, workers who perform more analytical tasks, or tasks requiring interpersonal

\footnotetext{
${ }^{1}$ Ostry and others (2018) and Hsieh and others (2013) show large productivity losses associated with lower female labor force participation across advanced and developing countries.

${ }^{2}$ While this result is suggestive of a trend towards decreasing gender differences in labor market opportunities, caution should be exercised in interpreting this trend given the cross-sectional nature of the data. Our findings are consistent, nevertheless, with those in Hsieh and others (2013), showing that labor market barriers to female employment in male-dominated occupations have decreased dramatically since 1960 in the United States.

${ }^{3}$ Autor, Levy, and Murnane (2003) show that routine-task intensity predicts workers' exposure to computerization in the US. Goos, Manning, and Salomons (2014) extend the task-based approach to 16 western European countries to show that routine-biased technological change decreases employment for middle-skill occupations. Using data on occupational distribution of 85 countries, Das and Hilgenstock (2018) find that developing economies are significantly less exposed to routinization than advanced economies, but the risks of routinization have risen globally over time.
} 
communication ("abstract" tasks) are less likely to be displaced. ${ }^{4}$ In contrast to these studies, we use individual-level data for a large sample of countries, which allows us to relax two crucial assumptions: (i) workers perform identical tasks within occupations across countries; and (ii) workers have access to the same technologies across countries to perform their tasks. In this respect, our paper is similar to De La Rica and Gortazar (2016) who use the PIAAC data to show that ICT adoption at work explains over 6 percent of the cross-country differences in job deroutinization in 22 OECD countries. However, these studies do not examine the implications of automation and technological progress separately for men and women.

Our paper is also related to studies that use occupational and task-level data to examine how women's labor market outcomes differ from those of men. Using occupational data from the US, Bacolod and Blum (2010) and Cortes, Jaimovich, and Siu (2018) find that women are more likely than men to be engaged in occupations requiring greater cognitive and interpersonal skills. These studies find that the recent increase in the returns to cognitive and interpersonal skills relative to motor skills has resulted in a narrowing of the gender-wage gap in the US. Black and Spitz-Oener (2010) show that relative increases in non-routine analytic or interactive task performed by women explains nearly 50 percent of the gender wage convergence in Germany ${ }^{5}$. Beaudry and Lewis (2014) show that the decline of the gender wage gap in the US is coincident and causally driven by the rate of computer adoption in local labor markets, where technology adoption increases the returns to brains relative to brawn. Much of this literature is limited to single country case-studies, predominantly the US, owing to the lack of standardized data across multiple countries on occupational characteristics.

Finally, our paper is related to studies that quantify gender differences on potential job losses in the future. The World Economic Forum's 2016 report on The Future of Jobs uses perceptionsbased surveys of Chief Human Resource Officers of leading employers globally to identify workforce disruption by industry, country and industry-gender gaps. Using 2022 projections on occupations' growth from data for the US, the report concludes that, worldwide, "men will face nearly 4 million job losses and 1.4 million gains..., whereas women will face 3 million job losses but only 0.55 million gains - more than five jobs lost for every job gained" (WEF, 2016). The International Labour Organization employs a similar methodology of stakeholder surveys to predict workforce disruption in ASEAN economies (ILO, 2016). One of the main drawbacks of these studies is their application of a universal index of how likely an occupation will be automated for both men and women. The WEF report applies predictions based on a US survey of occupations to a broad set of countries. However, men and women can perform different sets

\footnotetext{
${ }^{4}$ Acemoglu and Restrepo (2017) show theoretically that while automation and artificial intelligence reduce demand for labor in some tasks, productivity gains associated with this process can generate higher demand for labor in non-automated tasks.

${ }^{5}$ Black and Spitz-Oener (2010) show that the level of routineness of women's jobs is lower than for men in Germany in 1999. However, their sample is drawn only from West Germany, for individuals aged 25-55 years, which may account for differences between their conclusions and ours.
} 
of tasks even within the same occupation. Further, existing evidence suggests that occupational tasks vary non-trivially across countries.

The remainder of the paper is organized as follows: Section II outlines our measure of routineness and documents gender gaps in routineness across countries, occupations and sectors. Section III presents estimates for the probability of automation and evaluates gender gaps in exposure to automation. Section IV elaborates on intergenerational differences in the gender automation gap, highlighting differences in educational attainment and occupational and sector differences. Section V concludes.

\section{Measuring Exposure To Routinization: The RTI IndeX}

\section{A. Measuring Routineness}

The standard measure of job routineness —an index of routine task intensity (RTI) — developed by Autor, Levy, and Murnane (2003) quantifies the extent of codifiability of tasks performed on the job and serves as a proxy for substitutability of workers and machines. Jobs with a higher share of tasks that can be performed by following a defined set of rules, and are thus easily codifiable, score higher on the RTI index. Jobs requiring analytical, communicational, and technical skills score low on the RTI index. The construction of the RTI index therefore requires detailed information on task composition at work. To date, the literature on routinization has predominantly relied on the Dictionary of Occupational Titles (DOT) data produced by the US Department of Labor for occupation in the US, limiting the scope for cross-country comparisons.

We use the OECD's PIAAC database to develop a new cross-country index of job routineness from task composition at work. The PIAAC survey covers adults 16 to 65 years of age and collects detailed information on task composition, task frequency, and extent of ICT use in the workplace for 28 OECD member countries, as well as Cyprus and Singapore. ${ }^{6}$ In addition, the survey contains demographic information and measures of literacy, numeracy, and problem-solving skills for each respondent.

To construct the routine task intensity (RTI) index, we follow the method outlined in Autor and Dorn (2013), modified by De La Rica and Gortazar (2016), to match the content of the PIAAC survey. We calculate the RTI index at the individual-level using task composition at work of each survey respondent. The RTI index evaluates the relative importance of abstract skills, such as reasoning and interpersonal communication and non-routine manual skills against routine tasks which can be easily automated. Specifically, we calculate RTI for each individual worker $i$ as follows:

$$
\text { RTI }_{i}=\text { Routine }_{i}-\text { Abstract }_{i}-\text { Manual }_{i}
$$

\footnotetext{
${ }^{6}$ See Annex I for details on country and variable coverage.
} 
in which Routine $_{i}$, Abstract $_{i}$, and Manual $_{i}$ are index values of routine, abstract, and non-routine manual skills, respectively. The RTI index ranges from zero to one, with higher values indicating that a worker engages in more routine activities.

Table 1 lists the variables used for construction of the RTI index. Most country questionnaire items contain five responses indicating the frequency at which a task is performed: never, less than once a month, less than once a week but at least once a month, at least once a week but not every day, and every day. The "abstract" component consists of analytical and interpersonal tasks (e.g., writing reports, solving complex problems, and negotiating with people). We consider two types of manual tasks. These include routine tasks involving hand and finger dexterity and nonroutine physical work associated with caregiving and operating construction-related equipment. Since the PIAAC survey provides information on only two types of manual tasks, we classify them as routine and non-routine based on previous work by Autor, Levy, and Murnane (2003) and De La Rica and Gortazar (2016). The "routine" component consists of limited flexibility and limited on-the-job learning, low values of which indicate the repetitive nature of work and tasks that can be easily codified.

Table 1. Questionnaire Items Used to Construct RTI

\begin{tabular}{|c|c|c|}
\hline \multicolumn{2}{|c|}{ Index Component } & \multirow[b]{2}{*}{$\begin{array}{l}\text { Questionnaire Item } \\
\text { Read diagrams, maps or schematics } \\
\text { Write reports } \\
\text { Solve complex problems } \\
\text { Persuade or influence people } \\
\text { Negotiate with people }\end{array}$} \\
\hline RTI: Abstract & & \\
\hline RTI: Routine & $\begin{array}{l}\text { Lack of learning on the job } \\
\text { Manual routine }\end{array}$ & $\begin{array}{l}\text { Change sequence of task (inverse) } \\
\text { Change how to do work (inverse) } \\
\text { Change speed of work (inverse) } \\
\text { Change working hours (inverse) } \\
\text { Learn work-related things from coworkers (inverse) } \\
\text { Learn by doing (inverse) } \\
\text { Keep up to date with new products and services (inverse) } \\
\text { Hand and finger dexterity }\end{array}$ \\
\hline RTI: Non-rou & Manual & Perform physical work for long hours \\
\hline
\end{tabular}

Sources: PIAAC survey.

We perform a principal component analysis (PCA) to derive an index for each RTI component. ${ }^{7}$ For the routine component of RTI, we first perform a PCA on variables describing flexibility and learning on the job separately. Using an inverse of the resulting flexibility and learning indices,

\footnotetext{
${ }^{7}$ We adhere closely to the definition of RTI index adopted by De La Rica and Gortazar (2016) for the PIAAC dataset. However, we test for alternate definitions using different variables (where available) to ensure that our results are robust to variable choice (results available upon request). We also test for the correlation of the RTI index with the probability of automation index (Section III, Table 5) and find that the overall index and each subcomponent have the expected signs.
} 
along with the routine manual component, we use PCA to construct a composite routine component. Each subcomponent (abstract, routine and manual) is standardized to lie between zero and one. Finally, we construct the RTI index by subtracting abstract and manual components from the routine component and standardize the final index score to lie between zero and one.

\section{B. The Gender RTI Gap}

The RTI index, on average, is 13 percent higher for female workers across our sample of 30 countries (Table 2), a result that is statistically significant. This gender RTI gap - the ratio of the female to the male RTI level—is driven by female workers performing fewer tasks requiring analytical and interpersonal skills or physical labor, and more tasks that are characterized by lack of job flexibility, little learning on the job, and greater repetitiveness. This implies that female workers are more exposed to automation than male workers, on average, across our sample.

Table 2. Gender Differences in RTI Components

\begin{tabular}{lcccc}
\hline \hline & RTI Level & Abstract & Manual & Routine \\
\hline Female & 0.52 & 0.48 & 0.40 & 0.51 \\
Male & 0.46 & 0.56 & 0.47 & 0.47 \\
T-test p-value & 0.00 & 0.00 & 0.00 & 0.00 \\
\hline \hline
\end{tabular}

Sources: PIAAC survey; and IMF staff estimates.

Note: The RTI index ranges from zero to one, with higher values indicating that a worker engages in more routine activities. The t-test evaluates whether there is a significant difference between the mean values for males and females.

The sample average masks significant cross-country heterogeneity (Appendix Table A2). The level of female RTI is highest in Eastern and Southern European countries and lowest in Scandinavian and Central European countries. For instance, the RTI index level for female workers in Lithuania is 36 percent higher than in Norway. There are also marked differences in gender RTI gaps, which capture the relative routineness of female versus male jobs. Within Europe, while Estonia and the Slovak Republic have the highest gender RTI gaps, Greece exhibits much lower gender RTI gaps. Outside Europe, Japan and Singapore exhibit the highest gender RTI gaps in our sample. This heterogeneity is indicative of countries' positions along the automation path as well as crosscountry differences in selection of women into the labor force. It can also reflect differences in the structure of production (e.g., manufacturing vs. services sectors which require interpersonal communication), technologies adopted, and labor market flexibility, and thus differential distribution of workers across sectors and occupations (IMF 2018; Das and Hilgenstock 2018). 8

\footnotetext{
${ }^{8}$ Das and Hilgenstock (2018) show that exposure to routinization is driven by the declining price of investment goods, the structure of employment (high manual-intensive agriculture versus high routine-intensive clerical work) and job offshoring, in advanced economies. IMF (2018) finds significant cross-country variation in ICT prices and rapid growth of the gig economy, both of which may affect our estimates of job routineness levels.
} 


\section{Figure 1. Relationship Between Female Labor Force Participation and Size of Manufacturing Sector and the Gender RTI Gap}
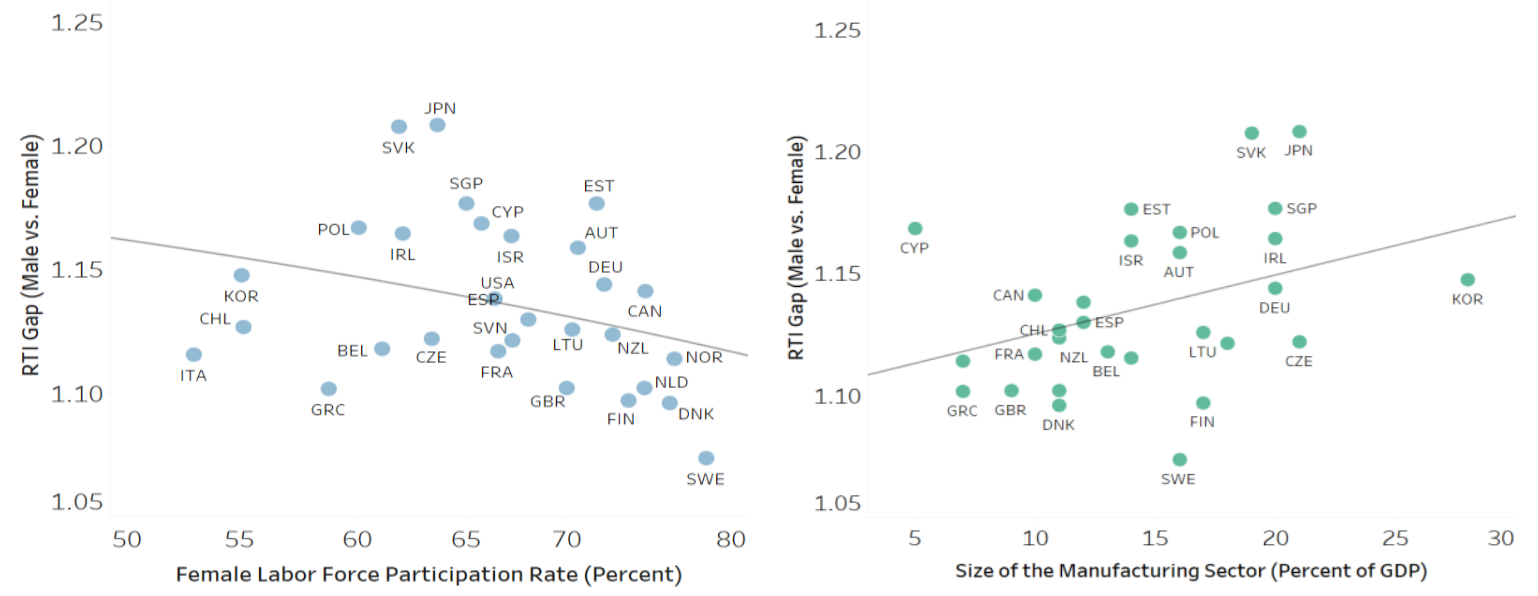

Sources: International Labour Organization; PIAAC survey, World Bank, World Development Indicators; and IMF staff calculations.

Note: RTI = routine task intensity. RTI gap= Female RTI/Male RTI.

We find that the gender RTI gap is correlated with the female labor force participation (FLFP) in a country (Figure 1). Gender RTI gaps are smaller in countries with higher FLFP, suggesting that a more equal representation of women and men in the workplace is associated with more equal division of tasks between men and women. We also find that gender RTI gaps are positively associated with the size of manufacturing sector (as a percentage of GDP). In other words, countries with larger manufacturing sectors tend to exhibit larger gender RTI gaps. This relationship is supported by existing research which shows that services tend to be more gender equal in employment than manufacturing (Weinberg, 2000; Borghans, Ter Weel, and Weinberg, 2014; Ostry and others, 2018). ${ }^{9}$ Hence, structural transformation away from manufacturing and towards a large service-based economy not only implies greater labor force participation of women on the "extensive margin," but can also lead to a more equal division of tasks between genders.

\section{Decomposing the Gender RTI Gap}

To better understand the determinants of the gender RTI gap, we decompose the RTI gender gap into contributions from individual and job characteristics (e.g., age, numeracy and literacy

\footnotetext{
${ }^{9}$ This correlation can be driven by both the gender differences in RTI within the manufacturing sector and differences in RTI between the manufacturing sector and other sectors. In our data we find suggestive evidence for both channels (Table A4) with Manufacturing, Transport and Construction having higher average female RTI and higher gender RTI gaps than, for instance, Health, Education and Retail trade services.
} 
skills, etc.), worker's education, and occupational and sectoral choices. In particular, we estimate the following specification:

$R_{T} I_{i}=\beta_{0}+\beta_{1}$ Female $_{i c}+\sum_{\text {ind }} \beta^{\text {ind }} X_{i c}^{\text {ind }}+\sum_{\text {ability }} \beta^{\text {ability }} X_{i c}^{\text {ability }}+\sum_{j o b} \beta^{j o b} X_{i c}^{j o b}+\alpha_{o}+\sigma_{s}+\tau_{c}+$ $\epsilon_{i c}$

where $\beta_{0}$ is a constant; Female $i c$ is a binary (0/1) indicator for female workers; $X_{i c}^{\text {ind }}$ are individual controls including age, level of education, presence of a partner and children, and immigrant status; $X_{i c}^{a b i l i t y}$ are numeracy, literacy, and problem-solving test scores; $X_{i c}^{j o b}$ include experience, on-the-job training, and part-time status; $\alpha_{o}$ is occupation fixed effects; $\sigma_{s}$ is sector fixed effects; $\tau_{c}$ is country fixed effects; and $\epsilon_{i c}$ is a normally distributed error term, with standard errors clustered at the country level.

For the decomposition, we first estimate the coefficient on the female indicator without any additional controls to derive an unconditional gender gap in the RTI index. We then estimate the full model to pin down the conditional gender RTI gap and examine how much of the change in the unconditional gender gap can be attributed to different control variables, using the decomposition method outlined in Gelbach (2012). The decomposition results show that almost 13 percent of the unconditional gender RTI gap is explained by occupational choice (Table 3).

These results indicate that women's job positions within occupations and therefore the types of tasks that they perform ("the intensive margin") are the main driver of gender disparities in routineness in the work place.

Table 3. RTI Decomposition: Drivers of RTI Gap

\begin{tabular}{|c|c|c|c|c|}
\hline & Unconditional & Conditional & Gap Explained & $\begin{array}{c}\text { Percent of gap } \\
\text { explained }\end{array}$ \\
\hline Male-Female RTI Gap & $\begin{array}{c}0.07 \\
(0.01)\end{array}$ & $\begin{array}{c}0.05 \\
(0.00)\end{array}$ & $\begin{array}{c}0.01 \\
(0.01)\end{array}$ & $18.82 \%$ \\
\hline Covariates & & & & \\
\hline $\begin{array}{l}\text { Age, numeracy, } \\
\text { literacy, training }\end{array}$ & & & $\begin{array}{c}0.00 \\
(0.00)\end{array}$ & $6.07 \%$ \\
\hline Education & & & $\begin{array}{l}-0.00 \\
(0.00)\end{array}$ & $-0.87 \%$ \\
\hline Sector & & & $\begin{array}{c}0.00 \\
(0.00)\end{array}$ & $0.92 \%$ \\
\hline Occupation & & & $\begin{array}{c}0.01^{* * *} \\
(0.00)\end{array}$ & $12.70 \%$ \\
\hline
\end{tabular}

Sources: PIAAC survey; and IMF staff calculations

Note: $\mathrm{RTI}=$ routine task intensity. Statistical significance levels: ${ }^{* *} p<0.01 ;{ }^{* *} p<0.05 ;{ }^{*} p<0.1$.

Since our decomposition results indicate that women's occupational choices are the largest contributor to the gender RTI gaps, we analyze within-occupation gender RTI gaps in Figure 2 
(Table A3 in Appendix). ${ }^{10}$ We find that gender RTI gaps persist across all occupations but are lower among professionals and managers-occupations which also exbibit a lower average level of routineness of tasks. These occupations, however, make up a smaller share of women's overall employment, indicating that women are potentially less insulated from automation owing to their occupational choices. For instance, while over 30 percent of the female labor force works in professional occupations (relative to 25 percent of the male labor force), only 8 percent are managers, legislators and senior officials, relative to 15 percent among males. On the other hand, 20 percent of working females in our sample hold clerical positions relative to only 8 percent of males, with clerical occupations having the second largest gender RTI gap.

\section{Figure 2. Gender Differences in RTI by Occupation}

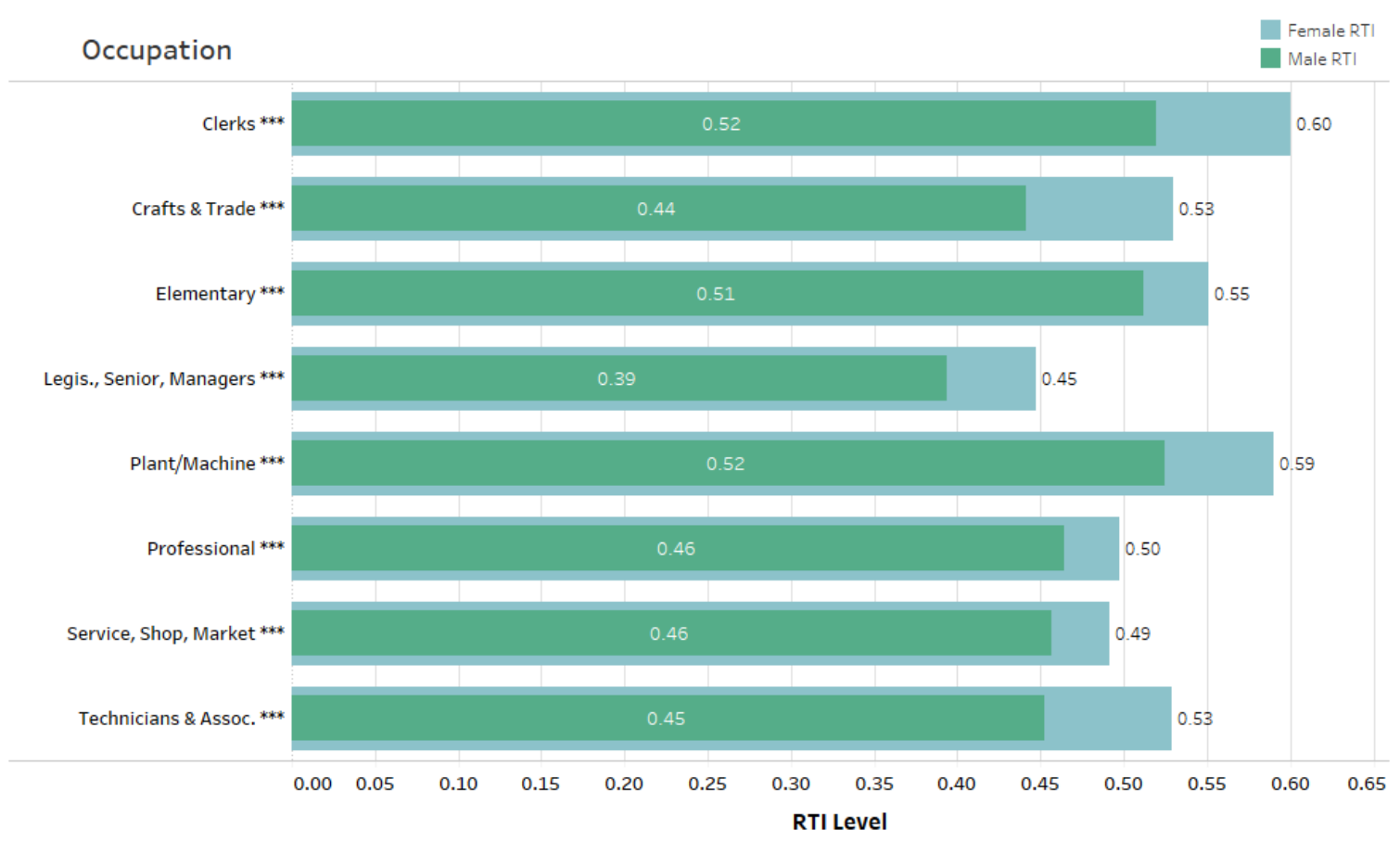

Sources: PIAAC survey; and IMF staff calculations.

Note: Note: RTI = routine task intensity. Bars represent respectively average male and female RTI indices for each occupation. The occupational classification corresponds with the respondent's 2-digit ISCO code. Statistical significance levels on the occupations reflect t-tests of the difference between male and female means of the RTI index. Statistical significance levels: *** $p<0.01 ;{ }^{* *} p<0.05 ;{ }^{*} p<0.1$.

Table A4 in the Appendix shows the sectoral distribution of female workers. With the exception of retail trade and services, a sector which employs a significant proportion of the female labor force and has a large gender RTI gap (corresponding female-to-male ratio of RTI is 1.19), other sectors that employ large proportions of the female labor force (e.g., health and education) also

\footnotetext{
${ }^{10}$ Occupation categories are based on the International Standard Classification of Occupations (ISCO-08). Sector categories are based on the International Standard Industrial Classification (ISIC rev. 4).
} 
tend to exhibit lower gender RTI gaps. This suggests that greater participation by women on the "extensive margin" in a sector can potentially lower their relative exposure to job automation.

\section{Risk Of AUtOMATION AND the FUtURE OF WORK FOR WOMEN}

\section{A. Estimating the Probability of Automation}

In this section we analyze how differences in task composition of men's and women's jobs translate into their relative likelihoods of being automated by estimating the probabilities of automation at the individual level.

The starting point of our analysis is the probability of automation estimates constructed by Frey and Osborne (2017). These estimates are based on the occupational classification and job task descriptions from O*NET and rankings created by a panel of machine learning researchers of job automatability given "state of art computer-controlled equipment" and availability of big data. ${ }^{11}$ To construct a measure of an occupation's susceptibility to automation, Frey and Osbourne (2017) use a two-stage process. In the first stage, a subset of occupations is hand-labeled into two categories, "automatable" or "non-automatable," by machine learning experts. In the second stage, a probabilistic model is used to impute the probability of automation from the handlabeled sample to the full sample of occupations using nine specific job task characteristics contained in the O*NET data that are deemed to constitute bottlenecks in automatability. The resulting dataset contains 702 occupations and their associated probabilities of automation on a continuous scale between 0 and 100 percent.

Probabilities of automation provide an intuitive and forward-looking measure of the likelihood that an occupation can be codified and performed by a computer. However, there are two key drawbacks of assigning probabilities of automation solely based on the individual's occupation. First, estimating automation probabilities at the occupational level assumes that all tasks within an occupation are automatable. This is likely to overstate automation probabilities, given that many occupations will entail a mix of tasks, not all of which can be automated at the current level of technology. Second, this method assumes that differences between men's and women's exposure to automation only arises from different modes of participation in occupations. This assumption obscures the fact that gender differences in exposure to automation can also arise from variation in task assignment at the workplace. To remedy this, we apply the method developed by Arntz, Gregory, and Zierahn (2017) to impute the probabilities to worker characteristics and job task descriptions from the PIAAC dataset. ${ }^{12}$

To relate automation probabilities at the occupational level to individuals, each observation in the PIAAC data is matched to the occupational codes in $\mathrm{O}^{*} \mathrm{NET}$ for which we have estimates of

\footnotetext{
${ }^{11} \mathrm{O}$ NET is a database maintained by the US Department of Labor containing detailed standardized information across nearly a thousand occupations in the US economy.

12 Hawksworth, Berriman, and Goel (2018) use a similar framework, but focus less on the gender dimension.
} 
automation probability from Frey and Osbourne (2017). Since the PIAAC data only contains 2digit ISCO codes for occupations, each observation can be mapped to multiple occupations in the Frey and Osbourne (2017) estimates. Therefore, in the spirit of Arntz, Gregory, and Zierahn (2017) we use the Expectation Maximization algorithm and estimate an individual-level regression:

$$
p_{i j}=\sum_{n=1}^{N} \beta_{n} X_{i n}+\epsilon_{i j}
$$

where $i$ denotes individuals, $j$ denotes duplicates of these individuals when multiple probabilities are associated with one individual due to differences in the aggregation level of occupations, $p_{i j}$ is the probability of automation, and $X_{i n}$ contains $\mathrm{N}$ individual, job, and task characteristics. $\beta_{n}$ are parameters which capture the impact of the regressors on probability of automation, which is restricted to the interval 0 to 100 percent.

We use a weighted Generalized Linear Model (GLM) for our estimation, with equal initial weights for all duplicates $j$ for individual $i$. For each iteration of the regression, we compare the prediction from our estimated model with the actual probability of automation from Frey and Osbourne (2017) and recalculate the weights as per Ibrahim (1990):

$$
w_{i j}=\frac{f\left(\hat{p}-p_{i j} \mid x_{i n}, \beta_{n}\right)}{\sum_{n=1}^{N} f\left(\hat{p}-p_{i j} \mid x_{i n}, \beta_{n}\right)},
$$

where $f($.$) is the standard normal density and \hat{p}$ is the predicted probability. Once weights converge and best fit is achieved, we use the estimated parameters $\beta_{n}$ to calculate the predicted probabilities of automation based on individual worker and job task characteristics. We estimate four models with minor variations in the set of regressors contingent on data availability. ${ }^{13}$ Table A5 in Appendix 2 shows model estimates based on variables that are common for all countries.

To test for robustness of our results, we use an alternative measure of automatability at the occupational level developed by Brynjolfsson, Mitchell, and Rock (2018). The "suitability for machine learning" (SML) index measures the degree to which machine learning has a potential to eliminate tasks within an occupation. There are two key differences between the SML index and probability of automation estimate by Frey and Osborne (2017). First, the SML index does not explicitly measure the likelihood of automation and its values exceed one. Therefore, interpretation of the SML index is less intuitive. Second, a more elaborate rubric for each set of tasks, or "direct work activities" (DWA), is used to assign subjective measures of automatability. Thus, the SML index is entirely based on subjective rankings. ${ }^{14}$ Higher values of the SML index

\footnotetext{
${ }^{13}$ Austria, Singapore, and Ireland do not have information on payment schemes; Cyprus, Spain, France, and Italy do not collect data on problem solving skills, and Canada does not collect information on payment scheme or job's educational requirement.

${ }^{14}$ As opposed to Frey and Osborne's (2017) method of categorizing each occupation based on the binary choice-automatable or non-automatable-Brynjolfsson, Mitchell, and Rock (2018) distribute a 23-question
} 
indicate higher capability of machine learning to substitute a worker in a given occupation. We apply the Expectation Maximization algorithm described above to map the occupation-level SML index to the individual level.

\section{B. Gender Differences in Probability of Automation}

\section{Cross-country Differences}

As can be seen from Table 4, women face a higher probability of automation than men. The average probability of automation among women in our sample is 40 percent, 2 percentage points higher than the average probability of automation among men-a difference that is statistically significant. The right panel of Table 4 focuses on workers at the highest risk of automation, defined as those with at least 70 percent probability of being displaced by current technologies in the next two decades. Women are 1.2 times more likely to be in the high-risk group-around 11 percent of women and 9 percent of men face a probability of automation higher than or equal to 70 percent.

Table 4. Gender Differences in Probability of Automation and SML

\begin{tabular}{|c|c|c|c|c|c|c|}
\hline \multirow[b]{2}{*}{ Measure of Automatability: } & \multicolumn{3}{|c|}{ Level } & \multicolumn{3}{|c|}{$\begin{array}{c}\text { Share of Workers at } \\
\text { High Risk of Automation } \\
\text { (percent, unless otherwise noted) }\end{array}$} \\
\hline & Female & Male & Ratio & Female & Male & Ratio \\
\hline Probability of Automation & 0.40 & 0.38 & $1.06^{* * *}$ & 10.65 & 8.84 & $1.20^{* * *}$ \\
\hline SML & 3.47 & 3.45 & $1.01^{* * *}$ & 27.04 & 6.70 & $4.04^{* * *}$ \\
\hline
\end{tabular}

Sources: Frey and Osbourne (2017); Brynjolfsson, Mitchell, and Rock (2018); PIAAC survey; and IMF staff estimates. Note: The probability of automation and SML are estimated using an expectation-maximization (EM) algorithm that relates individual characteristics (age, education, training, among other) and job task characteristics to occupational level risk of automation. High automatability is defined as having probability of automation $>=0.7$ or $\mathrm{SML}>=3.5$. Gender ratio $=$ female measure/male measure. Statistical significance levels on ratios reflect t-tests of the difference between male and female means or proportions of workers at high risk for a given measure. Statistical significance levels: ${ }^{* *} p<0.01 ;{ }^{* *} p<0.05 ;{ }^{*} p<0.1$.

The second row of Table 4 contains average predicted SML values by gender as well as the share of female and male workers at high risk automation (the $70^{\text {th }}$ percentile of the SML index). ${ }^{15}$ The results are consistent with our baseline findings for both average values of SML as well as shares of female and male workers at high risk of automation. In both cases, women have a higher exposure to machine learning than men, and these mean differences are statistically significant.

rubric on an online crowdsourcing platform to score each DWA on a 5-point scale. Rubric scores for each DWA are mapped to corresponding 966 occupations using task importance scores from O*NET.

${ }^{15} \mathrm{SML}$ index ranges from 3.19 to 3.63 in our sample, which gives us a threshold of 3.49 for the high-risk group. 
The difference between shares of men and women most exposed to machine learning is substantially larger when measured with the SML index compared with our baseline results. In particular, 27 percent of women compared to only 7 percent of men are at high risk of displacement by machines. These results provide further supporting evidence for our baseline estimates of women's susceptibility to automation.

How do the estimates for probability of automation compare to the RTI results? As foreshadowed in the previous section, the likelihood of automation increases with the RTI level. Our estimates for the probability of automation line up with Autor, Levy, and Murnane's (2003) task framework, with the probability of automation having a strong, statistically significant, positive relationship with the degree of routineness of work tasks and a statistically significant negative relationship with the abstract and manual components of the RTI index (Table 5).

Table 5. Correlation of RTI Components and Probability of Automation

\begin{tabular}{lcc}
\hline \hline & \multicolumn{2}{c}{ Probability of Automation } \\
\cline { 2 - 3 } RTI Index & $\mathbf{( 1 )}$ & $\mathbf{( 2 )}$ \\
Routine Index & $0.05^{* \star}$ & \\
& $(0.00)$ & $0.02^{\star * *}$ \\
Abstract Index & & $(0.00)$ \\
& & $-0.05^{\star * \star}$ \\
Manual Index & & $(0.00)$ \\
& & $-0.01^{* \star *}$ \\
Observations & & $(0.00)$ \\
\hline
\end{tabular}

Sources: Frey and Osbourne (2017); PIAAC survey; and IMF staff calculations.

Note: Routine task intensity (RTI) index is calculated at the individual level using information on routine, abstract, and manual tasks. Abstract index describes analytical and interpersonal tasks; manual index describes long hours of physical work (non-routine); routine index describes lack of job flexibility, little learning on the job, and repetitive tasks. Subcomponents of the routine index (lack of flexibility, lack of learning, manual routine) are also individually significant with a positive sign. The probability of automation is estimated using an expectation-maximization (EM) algorithm that relates individual characteristics (age, education, training, among other) and job task characteristics to occupational level risk of automation. Statistical significance levels: ${ }^{* *} p<0.01 ;{ }^{* *} p<0.05 ;{ }^{*} p<0.1$.

Country rankings of the gender gaps in probability of automation, both in levels and in the shares of high-risk workers (Table A6 in Appendix 2), are similar to the ranking of gender RTI gaps. In Japan, Singapore, and South Korea, women face a higher probability of being displaced by technology compared to men. However, this result is reversed in Sweden and Finland, where men face a greater likelihood of automation. These differences are statistically significant for both average probabilities of automation and relative shares of workers at high risk of automation. ${ }^{16}$ In France, the UK, and the US-countries with large service-dominated

\footnotetext{
16 Turkey is an outlier with respect to the gender differences in probability of automation. Labor market selection
} likely explains the gap reversal for a country with low female labor force participation such as Turkey. 
economies - the proportion of men and women in the workforce who face a high risk of automation is roughly similar.

\section{Individual Differences}

In this subsection, we explore the effects of individual and job characteristics on the susceptibility to automation (see Table A5 in Appendix 2). Workers spending a larger share of their time on selling, adhering to manuals, and using fingers and hands to complete the tasks, face a higher probability of automation. On the other hand, tasks such as trainings others, solving complex problems, and writing articles are associated with a lower risk or automation.

The likelihood of automation is decreasing in education, income level, and firm size. ${ }^{17}$ The risk of automation is less than 1 percent among workers who have a bachelor's degree or higher. The most disadvantaged group is women with lower secondary education or less, with nearly 50 percent at high risk of automation, relative to less than 40 percent of men with the same level of education. ${ }^{18}$ Interestingly, our analysis predicts that workers in small and medium enterprises (SMEs) have a higher risk of being automated as compared to workers in large enterprises (greater than 1000 workers). This may be a result of SMEs lagging behind large firms in their adoption of digital technologies, resulting in their workforce being more substitutable and less complementary with these technologies. ${ }^{19}$ Moreover, while female workers are significantly more likely than male workers to face risk of automation in SMEs, they are significantly less likely to face risk of automation in large firms relative to their male counterparts. This could reflect differences in firm policies regarding hiring or retention, or the selection of preferred workers into large firms. ${ }^{20}$

\section{Sectoral and Occupational Differences}

There is significant heterogeneity in the likelihood of automation across sectors and occupations (Figures 3 and 4). This evidence is consistent with the earlier finding that sectoral and occupational choices are important determinants of the gender RTI gaps. Overall, our analysis suggests that accommodation and food services, retail trade, and transportation face a high risk

\footnotetext{
17 Our estimates suggest that, all else equal, women face a lower probability of automation than their male counterparts. However, our predicted values of the probabilities of automation for men and women indicate that the average effect captured by the coefficient on the female indicator is smaller than the combined effects of other individual and job characteristics.

${ }^{18}$ Results are available upon request.

19 Deloitte (2017), for instance, finds that 80 percent of small businesses in the US are not fully utilizing digital technologies, and the biggest reason cited for their lack of use is not resource constraints, but a perceived irrelevance of technology to their work.

20 Theory and evidence indicates that large firms conduct more intensive searches for employees and provide more firm-specific human capital, which may result in less worker substitutability (Hu, 2003).
} 
of automation (Figure 3 and Table A7 in Appendix 2). While retail trade and accommodation and food services employ roughly similar proportions of the male and female workforce, men are disproportionately represented in the transport sector, and therefore more exposed to risk of automation owing to their sectoral choice. ${ }^{21}$ Women however, are vastly overrepresented in education, health, and social services - sectors which are at a relatively low risk of being automated. However, gender gaps in the risk of automation varies within sectors (Figure 3). For instance, despite the large share of female workers in education, women face a higher likelihood of being automated than men. This suggests that the extent to which female workforce is at risk of being automated depends not just on sectoral choices but also the job composition within a sector.

Figure 3. Gender Gap in High Risk of Automation Across Sectors

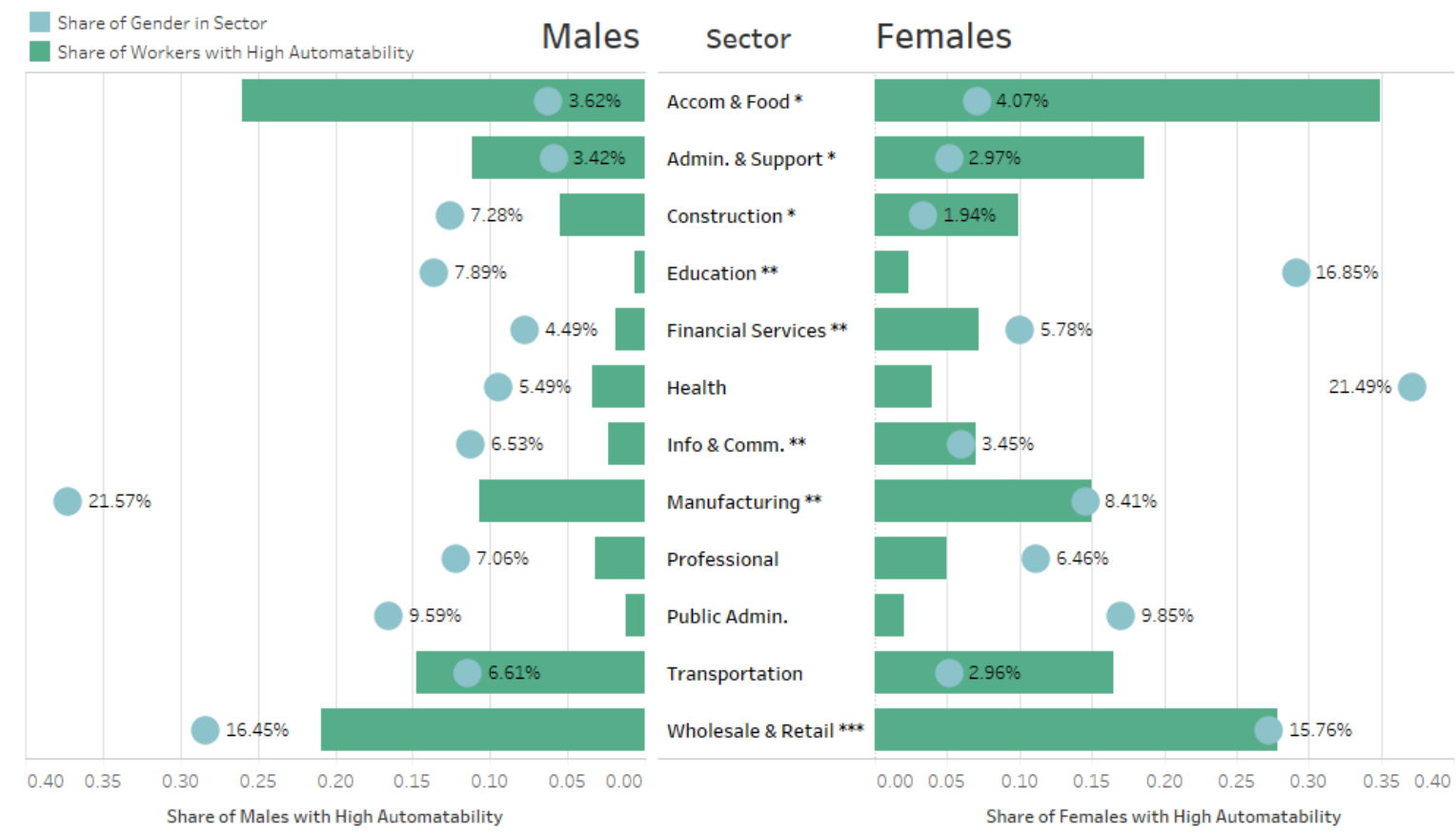

Sources: Frey and Osbourne (2017); PIAAC survey; and IMF staff estimates.

Note: The probability of automation is estimated using an expectation-maximization (EM) algorithm that relates individual characteristics (age, education, training, among other) and job task characteristics to occupational level risk of automation. Bars represents respectively the proportion of male and female workers at high risk of automation. High automatability is defined as having probability of automation $>=0.7$. Dots (and associated percentages) reflect the proportion of the male and female labor force employed in each sector. Statistical significance levels on the sectors reflect the t-test of the differences between proportions of male and female workers at high risk of automation. Statistical significance levels: ${ }^{* *} p<0.01$; ${ }^{* *} p<0.05$; * $p<0.1$.

\footnotetext{
${ }^{21}$ About 7 percent of the female workforce is employed in accommodation and food services relative to 5 percent of the male workforce. Retail trade employs 14 percent of the female and male workforce and is the second-largest employer of males and females overall.
} 
Figure 4. Gender Gap in High Risk of Automation Across Occupations

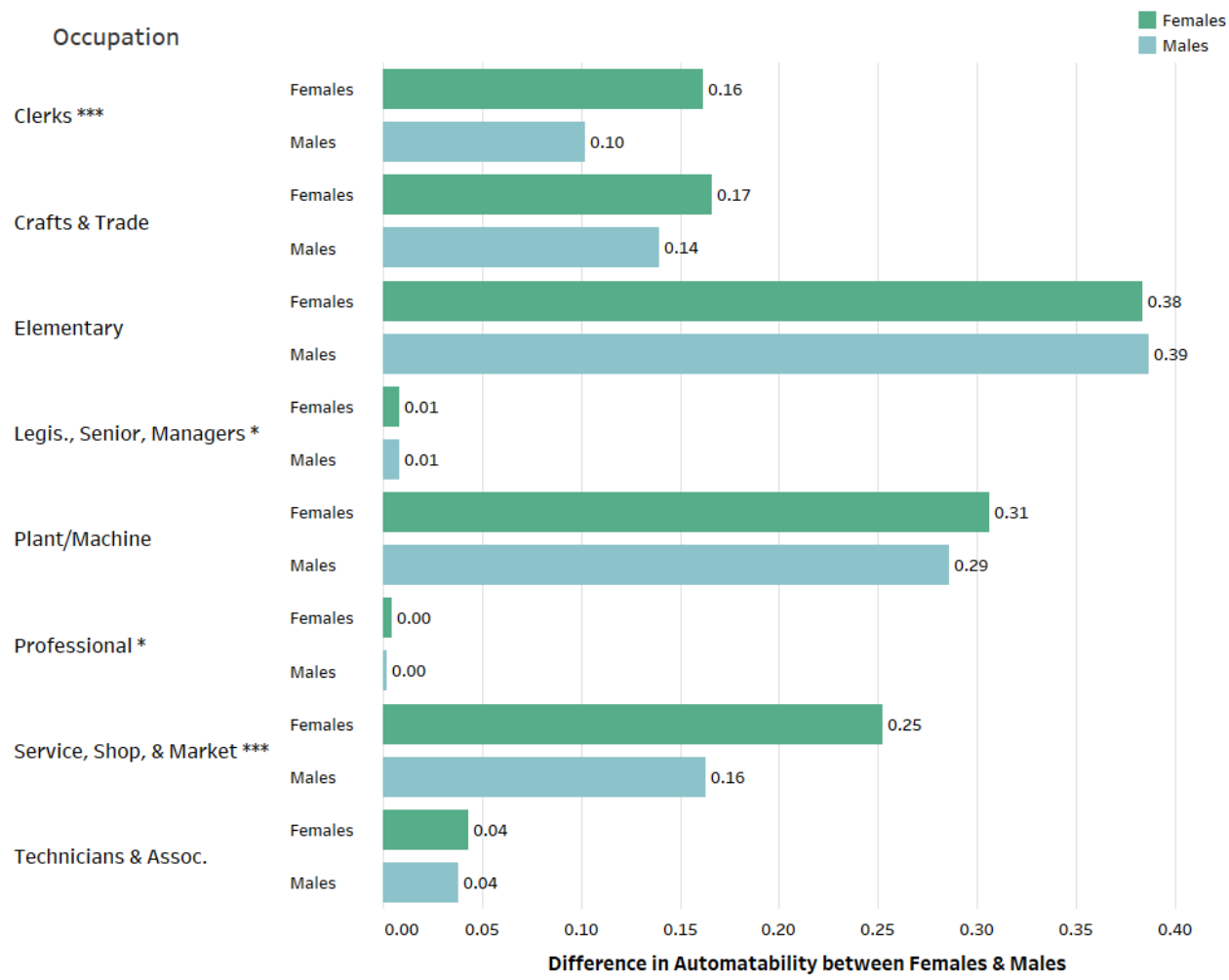

Sources: Frey and Osbourne (2017); PIAAC survey; and IMF staff estimates.

Note: The probability of automation is estimated using an expectation-maximization (EM) algorithm that relates individual characteristics (age, education, training, among other) and job task characteristics to occupational level risk of automation. Bars represents respectively the proportion of male and female workers at high risk of automation. High automatability is defined as having probability of automation $>=0.7$. Statistical significance level on the occupations reflects the t-test of the differences between proportions of male and female workers at high risk of automation. Statistical significance levels: ${ }^{* \star} p<0.01$; ${ }^{* \star} p<0.05$; * $p<0.1$.

The risk of automation also varies across occupations (Figure 4 and Table A8 in Appendix 2). Overall, elementary occupations, clerks, and service workers are most exposed to risk of automation, on average. Women are overrepresented among service workers and face a higher risk of automation than their male counterparts. ${ }^{22}$ Legislators, managers, and professionals are relatively insulated from the threat of displacement by automation, with less than 1 percent of the workforce (male and female) in these occupational categories being at high risk of automation. Among professionals while the threat from automation is overall low and women are at a lower risk of automation than men on average, they are also twice as likely as their male counterparts to be among the group of workers at highest risk for automation (Figure 4 and Table A8 in Appendix 2). In retail trade, where the overall risk of automation is very high, female workers are significantly less likely than male workers to perform abstract tasks-reflecting the

\footnotetext{
${ }^{22}$ About 20 percent of the overall female workforce falls under this occupation, relative to 13 percent of the male workforce.
} 
fact that there are fewer women in managerial positions. These findings suggest that the assumption of a homogeneous distribution of tasks across different workers within occupations is not supported by the data.

\section{Narrowing Gender Gaps Across Generations}

The previous sections highlight women's exposure to automation, but there are some positive trends. The distributional shift of women towards technical and professional occupations has accelerated in the last two decades. A shift-share analysis of jobs between 1994 and 2016, suggests that most job growth in OECD countries has been on the high-skill end, and that women have benefited from this trend more than men. ${ }^{23}$

Figure 5. Changes in Occupational Shares by Gender (1994-2016)

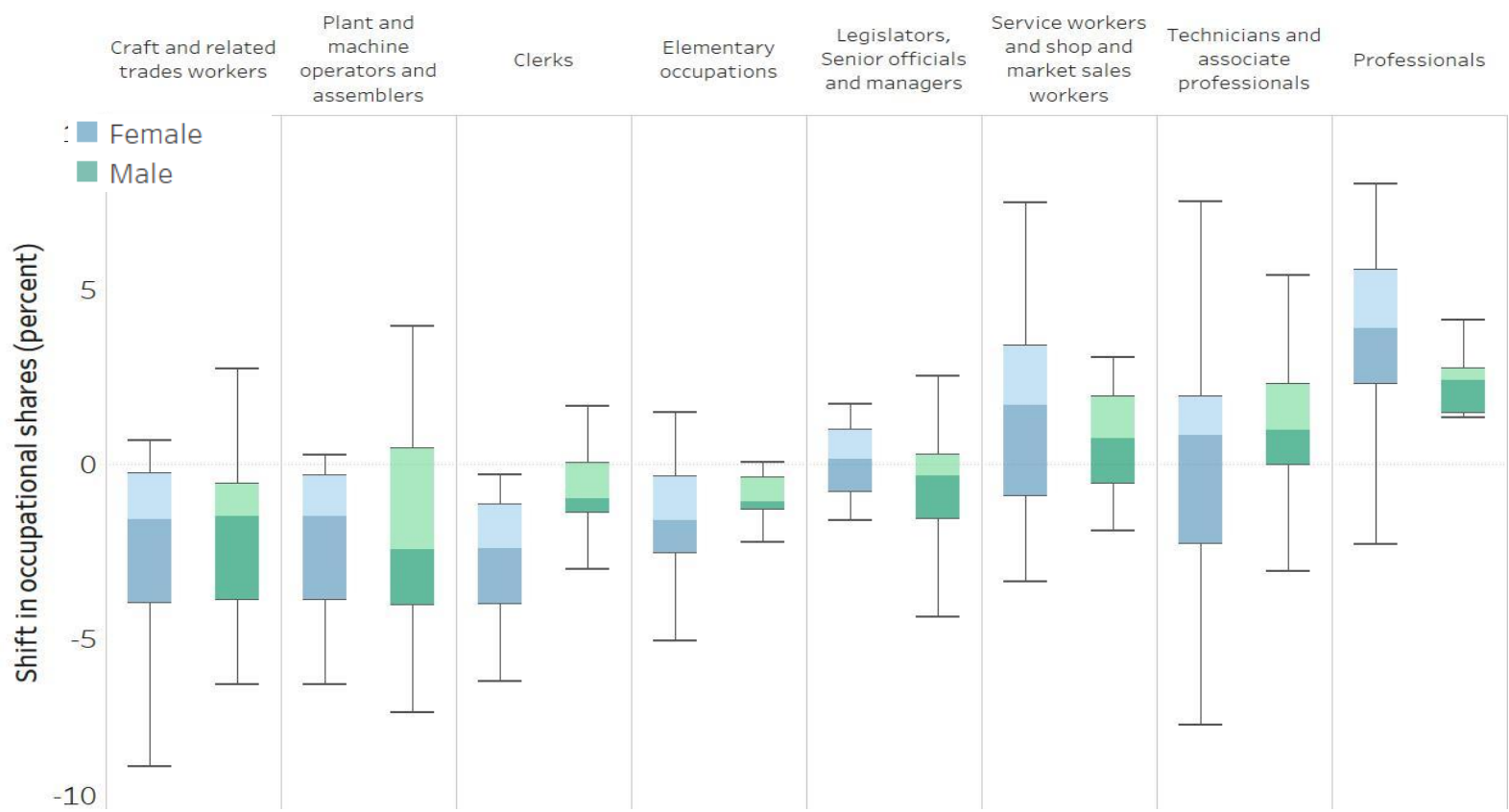

Sources: International Adult Literacy Survey; PIAAC survey; and IMF staff calculations.

Note: Shift in occupation is calculated as the difference between share of female (male) workers in occupation $X$ and country $Y$ in 1994, and the share of female (male) workers in the same occupation and country in 2016. Top and bottom values of the intervals represent country-specific maximum and minimum values for occupational share differences.

Figure 5 indicates an overall shift away from clerical occupations towards service and retail workers, technicians, and professionals-a trend that is more pronounced for women. Overall, women appear to be increasingly opting into occupations that are relatively more insulated from the risk of automation. ${ }^{24}$ However, there appears to be no significant increase in the numbers of

${ }^{23}$ Appendix 1 contains further details on the International Adult Literacy Survey used for this analysis.

24 These findings are also consistent with growing educational participation of women. According to the Pew Research Center, in 1994, slightly more than 60 percent of male and female graduates in the US were enrolled in university. By 2014, the figure for women had jumped to 71 percent, while that for men was broadly unchanged. 
women among legislators, senior officials and managers suggesting that while women may be entering more professional occupations, they have yet to increase their representation in leadership positions.

Figure 6. Gender Gaps in High Risk of Automation by Generation and Educational Level

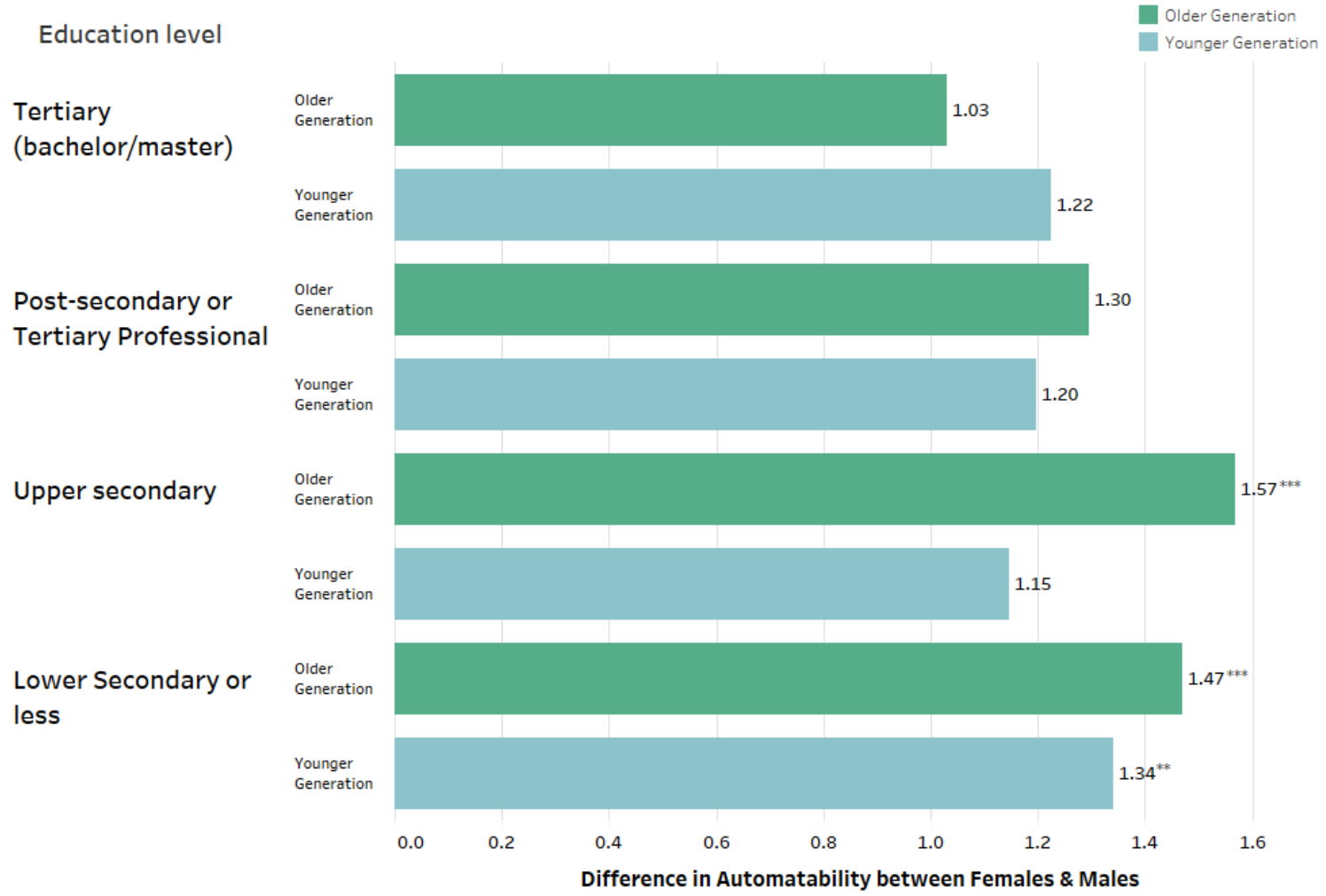

Sources: PIAAC survey; and IMF staff calculations.

Note: The probability of automation is estimated using an expectation-maximization (EM) algorithm that relates individual characteristics (age, education, training, among other) and job task characteristics to occupational level risk of automation. Bars represent the gender difference in automatability $=$ (Share of females at high risk for automation) / (Share of males at high risk of automation). High automatability is defined as having probability of automation $>=0.7$. Individuals between ages 20 and 39 are defined as younger generation. Individuals between ages 40 and 65 are defined as older generation. Statistical significance levels on bars reflect t-tests of the differences between proportions of male and female workers at high risk of automation. Statistical significance levels: ${ }^{* *} p<0.01 ;{ }^{* *} p<0.05 ;{ }^{*} p<0.1$.

We find that among both men and women, younger people are at the highest risk of losing their jobs to automation given current technologies. This is potentially driven by the selection of lesseducated workers into the labor force, given the high returns from human capital accumulation through education at this age. In addition, even highly educated youth tend to occupy more junior-level positions, which are more prone to automation, before moving to senior positions requiring more abstract skills. Moreover, automation can reduce employment, not merely by

More women than men are also completing college now than in the past, which has implications for their employment patterns and labor market prospects. 
replacing workers, but by potentially reducing new-job creation in some sectors or creating new high-skilled jobs, which is more likely to affect young entrants as opposed to older incumbents.

To further analyze intragenerational gender difference in the risk of automation, we divide our sample into a younger cohort (ages 20 to 39) including individuals born between early 1970s and mid-1990s, and an older cohort (ages 40 to 65) including individuals born between mid-1940s and early 1970s. Overall, we find that older cohorts of working women (older than 40) are at significantly higher risk for automation than men in the same age cohorts, suggesting greater disadvantage of women among older age groups. We further document a generational shift towards higher educational levels which are relatively insulated from risk of automation. Figure 6 shows that a higher share of women (1 percent) in younger generations received a tertiary degree than their older counterparts ( 0.4 percent). Moreover, while gender differences in tertiary education groups are not statistically significant for either older or younger generations, gender gaps in risk of automation have narrowed for less-well educated women, especially those with upper secondary education.

Table 6. Gender Gaps in High Risk of Automation by Generation and Occupation

\begin{tabular}{|c|c|c|c|c|}
\hline \multirow[b]{2}{*}{ Occupation } & \multicolumn{2}{|c|}{ Older Generation } & \multicolumn{2}{|c|}{ Younger Generation } \\
\hline & $\begin{array}{l}\text { Difference in } \\
\text { Automatability } \\
\text { (Female vs } \\
\text { Male) }\end{array}$ & $\begin{array}{c}\text { Female Share of } \\
\text { Occupation } \\
\text { (percent) }\end{array}$ & $\begin{array}{l}\text { Difference in } \\
\text { Automatability } \\
\text { (Female vs } \\
\text { Male) }\end{array}$ & $\begin{array}{c}\text { Female Share of } \\
\text { Occupation } \\
\text { (percent) }\end{array}$ \\
\hline Clerks & $1.88^{\star \star \star}$ & 21.48 & 1.11 & 19.44 \\
\hline Crafts \& trade & 1.44 & 1.14 & 1.04 & 1.47 \\
\hline $\begin{array}{l}\text { Elementary } \\
\text { Legislators, senior officials, }\end{array}$ & 1.50 & 1.51 & 0.79 & 1.77 \\
\hline$\&$ managers & 1.62 & 8.77 & 0.65 & 5.05 \\
\hline Plant/machine operators & 0.96 & 1.75 & 1.25 & 1.23 \\
\hline Professional & $4.51^{*}$ & 26.39 & 0.92 & 28.20 \\
\hline Service, shop, \& market & $2.01^{\star * *}$ & 15.36 & $1.58^{\star * \star}$ & 21.16 \\
\hline Technicians \& assoc. prof. & 1.28 & 23.60 & 1.02 & 21.12 \\
\hline
\end{tabular}

Sources: PIAAC survey; and IMF staff calculations.

Note: The probability of automation is estimated using an expectation-maximization (EM) algorithm that relates individual characteristics (age, education, training, among other) and job task characteristics to occupational level risk of automation. High automatability is defined as having probability of automation $>=$ 0.7. Individuals between ages 20 and 39 are defined as younger generation. Individuals between ages 40 and 65 are defined as older generation. Gender difference in automatability = (Share of females at high risk of automation) / (Share of males at high risk of automation). Female share of occupation is defined as the share of occupation in total female employment within a generation. Statistical significance levels on ratios reflect ttests of the differences between proportions of male and female workers at high risk of automation. Statistical significance levels: ${ }^{* * *} p<0.01 ;{ }^{* *} p<0.05 ;{ }^{*} p<0.1$. 
Table 6 documents a shift away from the clerical occupations and towards professional occupations for younger cohorts of women as well as narrowing of the gender gap within both occupations, consistent with the shift-share analysis presented in Figure 5. While the older cohort of women face a higher probability of automation than men in both clerical and professional occupations, this difference becomes statistically insignificant for younger generations and even reverses in the case of professionals. The automatability gap between genders also reverses in the case of legislators and senior managers across cohorts. ${ }^{25} \mathrm{~A}$ less encouraging trend pertains to the large automatability gap and rising share of women in service and retail occupations, which face the highest risk of automation.

Table 7. Gender Gaps in High Risk of Automation by Generation and Sector

\begin{tabular}{|c|c|c|c|c|}
\hline \multirow[b]{2}{*}{ Sector } & \multicolumn{2}{|c|}{ Older Generation } & \multicolumn{2}{|c|}{ Younger Generation } \\
\hline & $\begin{array}{c}\text { Difference in } \\
\text { Automatability } \\
\text { (Female vs Male) }\end{array}$ & $\begin{array}{l}\text { Female Share of } \\
\text { Sector (percent) }\end{array}$ & $\begin{array}{c}\text { Difference in } \\
\text { Automatability } \\
\text { (Female vs Male) }\end{array}$ & $\begin{array}{l}\text { Female Share of } \\
\text { Sector (percent) }\end{array}$ \\
\hline Accom. \& food & $1.76^{*}$ & 26.95 & $1.64^{* \star}$ & 33.14 \\
\hline Admin. \& support & $2.98^{\star *}$ & 25.39 & 0.98 & 13.06 \\
\hline Construction & $1.70^{\star * \star}$ & 9.12 & 1.73 & 9.64 \\
\hline Education & $3.93^{* *}$ & 2.86 & 1.31 & 0.61 \\
\hline Financial services & $7.73^{\star \star}$ & 9.20 & 1.85 & 4.61 \\
\hline Health & 1.43 & 4.76 & 0.91 & 3.04 \\
\hline Info. \& comm. & $2.54^{\star \star \star}$ & 3.05 & 1.56 & 4.82 \\
\hline Manufacturing & $1.82^{\star \star \star}$ & 16.89 & 1.13 & 13.21 \\
\hline Professional & $3.36^{\star \star}$ & 8.41 & 0.49 & 1.69 \\
\hline Public admin. & 1.97 & 2.76 & 1.04 & 0.94 \\
\hline Transportation & 1.16 & 14.58 & 0.96 & 17.38 \\
\hline Wholesale \& retail & $1.63^{* * *}$ & 26.92 & 1.19 & 25.07 \\
\hline
\end{tabular}

Sources: PIAAC survey; and IMF staff calculations.

Note: The probability of automation is estimated using an expectation-maximization (EM) algorithm that relates individual characteristics (age, education, training, among other) and job task characteristics to occupational level risk of automation. High automatability is defined as having probability of automation $>=$ 0.7 . Individuals between ages 20 and 39 are defined as younger generation. Individuals between ages 40 and 65 are defined as older generation. Gender difference in automatability $=$ (Share of females at high risk of automation) / (Share of males at high risk of automation). Female share of sector is defined as the share of sector in total female employment within a generation. Statistical significance levels on ratios reflect t-tests of the differences between proportions of male and female workers at high risk of automation. Statistical significance levels: ${ }^{\star \star *} p<0.01 ;{ }^{* \star} p<0.05 ;{ }^{*} p<0.1$.

\footnotetext{
${ }^{25}$ While we document a lower share of women in legislators and senior managers occupations in younger cohort compared to older cohorts, this likely reflects the fact that managerial positions are more likely to be reached at an older age.
} 
Finally, we compare inter-generational trends across sectors. Table 7 shows an across-the-board decline in women's relative exposure to automation for younger cohorts. Gender differences in the degree of automatability are statistically significant in almost all sectors for older generations. However, gender differences are substantially lower (four-fold in cases of education and financial services) and lose their statistical significance for younger cohorts of women. Accommodation and food services-one of the sectors most exposed to automation-is the only exception to this trend.

The overall positive trends displayed by the inter-generational analysis suggests that there is room for optimism about the future of work for women. An important caveat, however, is in order. Since our dataset does not allow us to track workers over time, these results could also reflect widening gender gaps in routinization and thus risk of automation over the women's lifecycle. Kleven, Landais, and Sogaard (2018), for instance, document that a large part of gender inequality in the labor market can be explained by a "child bearing penalty." Thus, our findings suggest an important role of policies for smoothing transitions of younger women workers and ensuring adequate safety nets for older, displaced workers.

\section{CONCLUSION}

Using individual-level data on task composition at work, this paper finds that women, on average, perform more routine tasks than men across all sectors and occupations-tasks that are most prone to automation. Given the current state of technology, we estimate that 26 million female jobs in 30 countries (28 OECD member countries, Cyprus, and Singapore) are at a high risk of being displaced by technology (i.e., facing higher than 70 percent likelihood of being automated) within the next two decades. Female workers face a higher risk of automation compared to male workers across all occupations, albeit with significant heterogeneity across sectors and countries.

There are some positive trends. Women's educational attainment has increased markedly in the last few decades in many developed economies. Further, women appear to be increasingly opting into occupations that are relatively more insulated from the risk of automation. The increase in women in professional roles and away from clerical and service positions is particularly encouraging in this regard, but more needs to be done. ${ }^{26}$ Across sectors and occupations, underrepresentation of women in managerial positions places them at high risk of displacement by technology.

Our estimates for the likelihood of automation assume current levels of technology and prevailing bottlenecks in the use of computer-controlled equipment. As such, our analysis presents a lower bound for the potential impact of automation. Given the speed of technological advancement in recent years, further improvements in the state of computing could result in more tasks being automated than predicted by the current level of technology. Our estimates are

\footnotetext{
${ }^{26}$ See Brussevich and other (2018) for an extensive discussion of the policy implications of technological change
} on female employment 
also based on the technological feasibility of automation as opposed to the economic feasibility: tasks could be automated given the current state of technology, but the costs of automation may be prohibitive relative to the prevailing cost of labor. Moreover, job losses could potentially be offset by new work opportunities created by technology and higher output potential owing to falling costs and prices. Finally, our analysis does not capture the emerging "gig" economyemployment in flexible, independent work arrangements - which could make it easier for women to combine paid work with family responsibilities, potentially improving their labor market outcomes.

Given considerable cross-country heterogeneity, ongoing work examines the drivers of gender RTI gaps across countries and evaluates differences in the probability of automation across sectors and countries. Further work on the gig economy is also warranted to assess the attendant opportunities and challenges for the future of work for women. 


\section{APPENDIX 1. Data and Definitions of RTI and ICT Use Indices}

The Organization for Economic Cooperation and Development (OECD) has administered the Programme for the International Assessment of Adult Competencies (PIAAC) surveys in two rounds between 2011 and 2016. In our sample, we include 30 countries, for which data are available (see Table A1 for country coverage and sample sizes). ${ }^{27}$ The survey covers adults between the ages of 16 to 65 and collects detailed demographic and work information for each respondent. In addition, PIAAC assesses respondents' numeracy, literacy, and problem-solving skills, which we use as proxies for workers' ability. Variables describing the frequency at which a respondent performs a set of tasks at work are particularly relevant to the analysis.

\section{Table A1. Country Sample Number of} Observations

\begin{tabular}{|c|c|c|}
\hline Country & PIAAC sample & IALS sample \\
\hline Austria & 3,737 & n.a. \\
\hline Belgium & 3,386 & 1,155 \\
\hline Canada & 19,403 & 4,683 \\
\hline Chile & 3,620 & 2,721 \\
\hline Cyprus & 2,807 & n.a. \\
\hline Czech Republic & 3,673 & 2,883 \\
\hline Denmark & 5,342 & 2,382 \\
\hline Estonia & 5,393 & n.a. \\
\hline Finland & 3,887 & 2,500 \\
\hline France & 4,523 & n.a. \\
\hline Germany & 4,070 & 1,141 \\
\hline Greece & 2,463 & n.a. \\
\hline Ireland & 3,677 & 1,291 \\
\hline Israel & 3,662 & n.a. \\
\hline Italy & 2,869 & 2,586 \\
\hline Japan & 3,881 & n.a. \\
\hline Korea & 4,428 & n.a. \\
\hline Lithuania & 3,218 & n.a. \\
\hline Netherlands & 3,942 & 1,924 \\
\hline Poland & 5,152 & 2,282 \\
\hline Singapore & 3,989 & n.a. \\
\hline Slovak Republic & 3,319 & n.a. \\
\hline Slovenia & 3,020 & 1,863 \\
\hline Spain & 3,386 & n.a. \\
\hline Sweden & 3,355 & 2,050 \\
\hline Turkey & 2,318 & n.a. \\
\hline United Kingdom & 5,911 & 4,582 \\
\hline United States & 3,560 & 2,697 \\
\hline
\end{tabular}

\footnotetext{
${ }^{27}$ We exclude the Russian sample because it is not representative for Moscow and the Moscow region. For Germany, we separately obtain wage data from the GESIS Leibniz Institute for the Social Sciences. Belgium PIAAC data covers the Flanders region only
} 
APPENDIX 2. Additional Tables

Table A2. Gender Differences in RTI by Country

\begin{tabular}{|c|c|c|c|c|}
\hline Country & $\begin{array}{c}\text { Female Labor Force } \\
\text { Participation Rate } \\
\text { (percent) }\end{array}$ & RTI Level (Female) & $\begin{array}{c}\text { RTI Gap } \\
\text { (female vs. male) }\end{array}$ & $\begin{array}{c}\text { T-test } \\
\text { (Male-Female) P } \\
\text { Val } \\
\end{array}$ \\
\hline Austria & 70.56 & 0.51 & 1.16 & 0.00 \\
\hline Belgium & 61.11 & 0.50 & 1.12 & 0.00 \\
\hline Canada & 74.18 & 0.53 & 1.14 & 0.00 \\
\hline Chile & 55.16 & 0.53 & 1.13 & 0.00 \\
\hline Cyprus & 65.75 & 0.58 & 1.17 & 0.00 \\
\hline Czech Republic & 63.39 & 0.50 & 1.12 & 0.00 \\
\hline Denmark & 75.53 & 0.49 & 1.10 & 0.00 \\
\hline Estonia & 71.57 & 0.56 & 1.18 & 0.00 \\
\hline Finland & 73.25 & 0.47 & 1.10 & 0.00 \\
\hline France & 66.54 & 0.53 & 1.12 & 0.00 \\
\hline Germany & 71.94 & 0.50 & 1.14 & 0.00 \\
\hline Greece & 58.73 & 0.59 & 1.10 & 0.00 \\
\hline Ireland & 62.05 & 0.55 & 1.16 & 0.00 \\
\hline Israel & 67.19 & 0.55 & 1.16 & 0.00 \\
\hline Italy & 53.18 & 0.59 & 1.12 & 0.00 \\
\hline Japan & 63.64 & 0.52 & 1.21 & 0.00 \\
\hline Lithuania & 70.29 & 0.64 & 1.13 & 0.00 \\
\hline Netherlands & 74.12 & 0.52 & 1.10 & 0.00 \\
\hline New Zealand & 72.43 & 0.50 & 1.12 & 0.00 \\
\hline Norway & 75.78 & 0.47 & 1.11 & 0.00 \\
\hline Poland & 60.05 & 0.56 & 1.17 & 0.00 \\
\hline Singapore & 65.02 & 0.56 & 1.18 & 0.00 \\
\hline Slovak Republic & 61.85 & 0.60 & 1.21 & 0.00 \\
\hline Slovenia & 67.26 & 0.56 & 1.12 & 0.00 \\
\hline South Korea & 55.11 & 0.55 & 1.15 & 0.00 \\
\hline Spain & 68.06 & 0.53 & 1.13 & 0.00 \\
\hline Sweden & 77.60 & 0.48 & 1.07 & 0.00 \\
\hline Turkey & 32.19 & 0.53 & 1.05 & 0.00 \\
\hline United Kingdom & 70.00 & 0.51 & 1.10 & 0.08 \\
\hline United States & 66.36 & 0.50 & 1.14 & 0.00 \\
\hline
\end{tabular}

Sources: International Labour Organization; PIAAC survey; and IMF staff calculations.

Note: $\mathrm{RTI}$ = routine task intensity. RTI gap= Female RTI/Male RTI. The t-test evaluates whether there is a significant difference between the mean values for males and females. 
Table A3. Gender Differences in RTI by Occupation

\begin{tabular}{lcccc}
\hline \hline Occupation & $\begin{array}{c}\text { Share of } \\
\text { Female } \\
\text { Workers } \\
\text { (percent) }\end{array}$ & $\begin{array}{c}\text { RTI Level } \\
\text { (Female) }\end{array}$ & $\begin{array}{c}\text { RTI Gap } \\
\text { (female vs. } \\
\text { male) }\end{array}$ & $\begin{array}{c}\text { T-test } \\
\text { (Male- } \\
\text { Female) P- } \\
\text { Value }\end{array}$ \\
\hline Professional & 30 & 0.50 & 1.07 & 0.00 \\
Technicians \& assoc. prof. & 21 & 0.53 & 1.17 & 0.00 \\
Legislators, senior officials, \& managers & 8 & 0.45 & 1.14 & 0.00 \\
Service, shop, \& market & 18 & 0.49 & 1.08 & 0.00 \\
Crafts \& trade & 1 & 0.53 & 1.20 & 0.00 \\
Clerks & 18 & 0.6 & 1.16 & 0.00 \\
Plant/machine operators & 1 & 0.59 & 1.12 & 0.00 \\
Elementary & 2 & 0.55 & 1.08 & 0.00 \\
\hline \hline
\end{tabular}

Sources: PIAAC survey; and IMF staff calculations.

Note: Note: RTI = routine task intensity. RTI gap= Female RTI/Male RTI. The share of female workers represents the proportion of the total female labor force that is employed in each occupational classification. The occupational classification corresponds with the respondent's 2-digit ISCO code. The t-test evaluates whether there is a significant difference between the mean values for males and females. 
Table A3.1. Occupational Classifications

\section{Occupation (ISCO 2 digit)}

Professional

Technicians \& assoc. prof.

Legislators, senior officials, \& managers

Clerks

Crafts \& trade

Service, shop, \& market

Plant/machine operators

Elementary

\section{Occupation (ISCO 4 digit)}

Science and engineering professionals

Health professionals

Teaching professionals

Business and administration professionals

Information and communications technology professionals

Legal, social and cultural professionals

Science and engineering associate professionals

Health associate professionals

Business and administration associate professionals

Legal, social, cultural and related associate professionals

Information and communications technicians

Chief executives, senior officials and legislators

Administrative and commercial managers

Production and specialized services managers

Hospitality, retail and other services managers

General and keyboard clerks

Customer services clerks

Numerical and material recording clerks

Other clerical support workers

Building and related trades workers, excluding electricians

Metal, machinery and related trades workers

Handicraft and printing workers

Electrical and electronic trades workers

Food processing, wood working, garment and other craft and

related trades workers

Personal service workers

Sales workers

Personal care workers

Protective services workers

Stationary plant and machine operators

Assemblers

Drivers and mobile plant operators

Cleaners and helpers

Agricultural, forestry and fishery laborers

Laborers in mining, construction, manufacturing and transport

Food preparation assistants

Street and related sales and service workers

Refuse workers and other elementary workers 
Table A4. Gender Differences in RTI by Sector

\begin{tabular}{lcccc}
\hline \hline Sector & $\begin{array}{c}\text { Share of } \\
\text { Female Workers } \\
\text { (percent) }\end{array}$ & $\begin{array}{c}\text { RTI Level } \\
\text { (Female) }\end{array}$ & $\begin{array}{c}\text { RTI Gap } \\
\text { (female vs. } \\
\text { male) }\end{array}$ & $\begin{array}{c}\text { T-test } \\
\text { (Male-Female) } \\
\text { P-Value }\end{array}$ \\
\hline Health & 21 & 0.48 & 1.05 & 0.00 \\
Wholesale \& retail & 16 & 0.51 & 1.19 & 0.00 \\
Education & 17 & 0.51 & 1.06 & 0.00 \\
Manufacturing & 8 & 0.54 & 1.17 & 0.00 \\
Public admin. & 10 & 0.55 & 1.16 & 0.00 \\
Financial services & 6 & 0.55 & 1.19 & 0.00 \\
Professional & 6 & 0.54 & 1.19 & 0.00 \\
Accom. \& food & 4 & 0.50 & 1.11 & 0.00 \\
Info. \& comm. & 4 & 0.54 & 1.17 & 0.00 \\
Admin. \& support & 3 & 0.53 & 1.15 & 0.00 \\
Transportation & 3 & 0.56 & 1.16 & 0.00 \\
Construction & 2 & 0.57 & 1.38 & 0.00 \\
\hline \hline
\end{tabular}

Sources: PIAAC survey; and IMF staff calculations.

Note: Note: RTI = routine task intensity. RTI gap= Female RTI/Male RTI. The share of female workers represents the proportion of the total female labor force that is employed in each sector. Sector classifications correspond to the respondent's 1-digit ISIC rev 4 industry code. The t-test evaluates whether there is a significant difference between the mean values for males and females. 
Table A5. Estimation of Probability of Automation

\begin{tabular}{|c|c|c|c|}
\hline Variable & $\begin{array}{l}\text { Probability of } \\
\text { Automation }\end{array}$ & Variable & $\begin{array}{c}\text { Probability of } \\
\text { Automation }\end{array}$ \\
\hline Female & $-0.08^{\star \star \star}$ & Computer use at work & $-0.02^{\star * \star}$ \\
\hline Age (20-24) & $-0.08^{\star \star *}$ & $\begin{array}{l}\text { Cooperating with others at } \\
\text { work }\end{array}$ & $-0.00^{*}$ \\
\hline Age (25-29) & $0.05^{\star \star \star}$ & Exchanging information & $0.85^{\star \star \star}$ \\
\hline Age (30-34) & $-0.07^{\star \star *}$ & Training others & $-2.89^{\star \star \star}$ \\
\hline Age (35-39) & $-0.03^{* * *}$ & Presenting & $-5.36^{\star \star \star}$ \\
\hline Age (40-44) & $0.02^{*}$ & Selling & $3.22^{* \star *}$ \\
\hline Age (45-49) & $0.02^{*}$ & Consulting & $0.34^{\star * \star}$ \\
\hline Age (50-54) & 0.02 & Planning own activities & $0.63^{* \star *}$ \\
\hline Age (55-59) & 0.00 & Planning activities of others & $-2.30^{\star \star \star}$ \\
\hline Age (60-65) & $0.13^{\star * \star}$ & Organizing own schedule & $-1.09^{\star \star \star}$ \\
\hline $\begin{array}{l}\text { Education Medium } \\
\text { (ISCED 3, 4, 5B) }\end{array}$ & $-0.26^{* \star *}$ & Influencing & $-4.44^{* \star \star}$ \\
\hline Education High (ISCED 5A, 6) & $-0.64^{* \star \star}$ & Negotiating & $0.49^{\star * \star}$ \\
\hline Numeracy Skills & 0.00 & Solving simple problems & $-0.77^{\star \star \star}$ \\
\hline Literacy Skills & $-0.00^{* \star *}$ & Solving complex problems & $-1.87^{\star \star \star}$ \\
\hline $\begin{array}{l}\text { Sector } \\
\text { (Private=0; Public/Non- } \\
\text { profit=1) }\end{array}$ & $-0.18^{\star \star *}$ & Work physically for long & $-0.31^{* * *}$ \\
\hline Firm Size (11-1000) & $0.07^{\star * *}$ & Fingers and hand use & $0.93^{* * *}$ \\
\hline Firm Size (>1000) & $-0.03^{* * *}$ & Reading instructions & $-1.47^{\star \star \star}$ \\
\hline $\begin{array}{l}\text { Responsibility for managing } \\
\text { staff }\end{array}$ & $0.13^{* * *}$ & $\begin{array}{l}\text { Reading professional } \\
\text { publications }\end{array}$ & $-4.85^{\star \star \star}$ \\
\hline Job experience requirement & $-0.08^{* \star \star}$ & Reading books & $-5.06^{\star \star *}$ \\
\hline Income decile 2 & $0.19^{\star \star \star}$ & Reading manuals & $0.24^{\star *}$ \\
\hline Income decile 3 & $0.18^{\star * \star}$ & Writing articles & $-4.53^{* * *}$ \\
\hline Income decile 4 & $0.08^{\star * \star}$ & Filling forms & $-0.87^{* \star *}$ \\
\hline Income decile 5 & $0.06^{* * *}$ & Calculating shares & $-0.37^{* * *}$ \\
\hline Income decile 6 & $-0.02^{*}$ & Complex math or statistics & $-1.78^{\star \star *}$ \\
\hline Income decile 7 & $-0.04^{* * *}$ & Using internet for work & $-1.32^{* * *}$ \\
\hline Income decile 8 & $-0.15^{\star \star *}$ & Using programming language & $-4.16^{\star \star \star}$ \\
\hline Income decile 9 & $-0.42^{* * *}$ & Using communication software & $-1.67^{* * *}$ \\
\hline Income decile 10 & $-0.44^{\star \star *}$ & Country Fixed Effects & Yes \\
\hline $\begin{array}{l}\text { Not challenged enough at } \\
\text { work }\end{array}$ & $-0.16^{\star \star *}$ & Constant & $1.33^{* * *}$ \\
\hline Need more training & $0.08^{\star * *}$ & $\mathrm{~N}$ & 65,876 \\
\hline
\end{tabular}

Sources: Frey and Osbourne (2017); PIAAC survey; and IMF staff estimates.

Note: The table contains cross-country regression results of the probability of automation (dependent variables) on individual and job characteristics. The probability of automation is estimated using an expectation-maximization (EM) algorithm that relates individual characteristics (age, education, training, among other) and job task characteristics to occupational level risk of automation. All task variables are measured in terms of shares of time and range from 0 to 1 . Statistical significance levels: ${ }^{* * *} p<0.01 ;{ }^{* *} p<0.05 ;{ }^{*} p<0.1$. 
Table A6. Gender Differences in Probability of Automation by Country

\begin{tabular}{|c|c|c|c|c|c|c|}
\hline \multirow[b]{2}{*}{ Country } & \multicolumn{3}{|c|}{ Probability of automation } & \multicolumn{3}{|c|}{$\begin{array}{c}\text { Share of workers at high risk of } \\
\text { automation (probability > =0.7) (in } \\
\text { percent, unless noted) } \\
\end{array}$} \\
\hline & Female & Male & Ratio & Female & Male & Ratio \\
\hline Austria & 0.48 & 0.43 & $1.11^{\star * *}$ & 15.84 & 10.09 & $1.57^{* * *}$ \\
\hline Belgium & 0.36 & 0.36 & 1.00 & 6.54 & 7.69 & 0.85 \\
\hline Canada & 0.41 & 0.39 & $1.04^{\star *}$ & 11.75 & 9.79 & $1.20^{* *}$ \\
\hline Chile & 0.38 & 0.34 & $1.10^{*}$ & 8.13 & 4.21 & $1.93^{*}$ \\
\hline Cyprus & 0.38 & 0.33 & $1.14^{\star \star \star}$ & 8.72 & 4.73 & $1.84^{*}$ \\
\hline Czech Republic & 0.44 & 0.42 & 1.03 & 9.76 & 6.90 & 1.41 \\
\hline Denmark & 0.39 & 0.40 & 0.97 & 9.70 & 10.88 & 0.89 \\
\hline Estonia & 0.36 & 0.35 & 1.04 & 8.59 & 6.26 & $1.37^{* *}$ \\
\hline Finland & 0.35 & 0.38 & $0.92^{* * *}$ & 6.98 & 10.60 & $0.66^{\star * *}$ \\
\hline France & 0.39 & 0.38 & 1.00 & 10.01 & 10.32 & 0.97 \\
\hline Germany & 0.44 & 0.39 & $1.14^{* * *}$ & 12.68 & 10.61 & 1.19 \\
\hline Greece & 0.38 & 0.42 & 0.91 & 12.34 & 16.65 & $0.74^{*}$ \\
\hline Ireland & 0.39 & 0.38 & 1.04 & 12.37 & 8.83 & $1.40^{*}$ \\
\hline Israel & 0.37 & 0.33 & $1.13^{\star \star *}$ & 12.76 & 5.44 & $2.34^{\star \star *}$ \\
\hline Italy & 0.43 & 0.46 & $0.94^{*}$ & 11.43 & 14.40 & 0.79 \\
\hline Japan & 0.44 & 0.34 & $1.30^{\star * *}$ & 14.28 & 4.20 & $3.40^{* \star *}$ \\
\hline Lithuania & 0.35 & 0.40 & $0.89 * * *$ & 8.12 & 8.40 & 0.97 \\
\hline Netherlands & 0.41 & 0.38 & $1.08^{* * *}$ & 12.01 & 9.90 & $1.21^{*}$ \\
\hline New Zealand & 0.38 & 0.37 & 1.02 & 10.12 & 6.67 & $1.52^{* \star *}$ \\
\hline Norway & 0.39 & 0.38 & 1.01 & 12.65 & 9.96 & $1.27^{\star *}$ \\
\hline Poland & 0.31 & 0.34 & $0.92^{*}$ & 4.87 & 6.72 & 0.72 \\
\hline Singapore & 0.36 & 0.30 & $1.18^{\star \star \star}$ & 8.59 & 5.06 & $1.70^{\star \star \star}$ \\
\hline Slovak Republic & 0.43 & 0.39 & $1.10^{\star \star *}$ & 10.48 & 9.04 & 1.16 \\
\hline Slovenia & 0.39 & 0.42 & $0.93^{* *}$ & 10.23 & 12.59 & 0.81 \\
\hline South Korea & 0.39 & 0.33 & $1.19 * * *$ & 10.34 & 4.29 & $2.41^{* * *}$ \\
\hline Spain & 0.38 & 0.37 & 1.02 & 12.63 & 10.49 & 1.20 \\
\hline Sweden & 0.38 & 0.40 & $0.94^{* *}$ & 9.77 & 11.22 & $0.87^{*}$ \\
\hline Turkey & 0.33 & 0.41 & $0.81^{\star \star *}$ & 4.89 & 14.49 & $0.34^{\star \star *}$ \\
\hline United Kingdom & 0.40 & 0.39 & 1.01 & 11.84 & 11.23 & 1.05 \\
\hline United States & 0.39 & 0.39 & 1.01 & 9.46 & 9.20 & 1.03 \\
\hline
\end{tabular}

Sources: Frey and Osbourne (2017); PIAAC survey; and IMF staff estimates.

Note: The probability of automation is estimated using an expectation-maximization (EM) algorithm that relates individual characteristics (age, education, training, among other) and job task characteristics to occupational level risk of automation. High automatability is defined as having probability of automation $>=0.7$. Gender ratio $=$ female measure/male measure. Statistical significance level on the ratio refers to the t-test of the differences between male and female averages. Statistical significance levels: ${ }^{* \star} p<0.01 ;{ }^{* *} p<0.05 ;{ }^{*} p<0.1$. 
Table A7. Gender Differences in Probability of Automation by Sector

\begin{tabular}{|c|c|c|c|c|c|c|}
\hline \multirow[b]{2}{*}{ Sector } & \multicolumn{3}{|c|}{ Probability of automation } & \multicolumn{3}{|c|}{$\begin{array}{c}\text { Share of workers at high risk of } \\
\text { automation (probability }>=0.7 \text { ) (in percent, } \\
\text { unless noted) }\end{array}$} \\
\hline & Female & Male & Ratio & Female & Male & Ratio \\
\hline Accom. \& food & 0.60 & 0.56 & $1.07^{*}$ & 34.91 & 26.00 & $1.34^{*}$ \\
\hline Admin. \& support & 0.50 & 0.46 & $1.11^{* *}$ & 18.63 & 11.20 & $1.66^{*}$ \\
\hline Construction & 0.49 & 0.39 & $1.26^{\star \star \star}$ & 9.93 & 5.53 & $1.80^{*}$ \\
\hline Education & 0.20 & 0.18 & $1.13^{* *}$ & 2.32 & 0.63 & $3.70^{* *}$ \\
\hline Financial services & 0.42 & 0.31 & $1.37^{\star \star \star}$ & 7.17 & 1.89 & $3.80^{* *}$ \\
\hline Health & 0.35 & 0.32 & $1.09^{* *}$ & 3.95 & 3.36 & 1.18 \\
\hline Info. \& comm. & 0.36 & 0.27 & $1.33^{\star * *}$ & 7.03 & 2.39 & $2.93^{* *}$ \\
\hline Manufacturing & 0.47 & 0.42 & $1.14^{\star * *}$ & 15.01 & 10.68 & $1.40^{* *}$ \\
\hline Professional & 0.36 & 0.28 & 1.30 *** & 4.92 & 3.20 & 1.54 \\
\hline Public admin. & 0.35 & 0.29 & $1.19 * * *$ & 2.02 & 1.19 & 1.70 \\
\hline Transportation & 0.52 & 0.49 & $1.07^{*}$ & 16.47 & 14.78 & 1.11 \\
\hline Wholesale \& retail & 0.57 & 0.53 & $1.08 * \star *$ & 27.85 & 20.90 & $1.33^{* * *}$ \\
\hline
\end{tabular}

Sources: Frey and Osbourne (2017); PIAAC survey; and IMF staff estimates.

Note: The probability of automation is estimated using an expectation-maximization (EM) algorithm that relates individual characteristics (age, education, training, among other) and job task characteristics to occupational level risk of automation. High automatability is defined as having probability of automation $>=0.7$. Gender ratio $=$ female measure/male measure. Statistical significance level on the ratio refers to the t-test of the differences between male and female means or proportions of workers at high risk of automation. Statistical significance levels: ${ }^{* * *} p<0.01$; ${ }^{* *}$ $p<0.05 ;{ }^{*} p<0.1$. 
Table A8. Gender Differences in Probability of Automation by Occupation

\begin{tabular}{|c|c|c|c|c|c|c|}
\hline \multirow[b]{2}{*}{ Occupation } & \multicolumn{3}{|c|}{ Probability of automation } & \multicolumn{3}{|c|}{$\begin{array}{l}\text { Share of workers at high risk of } \\
\text { automation (probability }>=0.7 \text { ) (in } \\
\text { percent, unless noted) }\end{array}$} \\
\hline & Female & Male & Ratio & Female & Male & Ratio \\
\hline Clerks & 0.54 & 0.46 & $1.16^{\star * *}$ & 16.15 & 10.24 & $1.58^{* * *}$ \\
\hline Crafts \& trade & 0.55 & 0.52 & $1.06^{*}$ & 16.60 & 13.95 & 1.19 \\
\hline Elementary & 0.64 & 0.64 & 1.00 & 38.35 & 38.65 & 0.99 \\
\hline $\begin{array}{l}\text { Legislators, senior officials, } \\
\text { managers }\end{array}$ & 0.24 & 0.23 & 1.04 & 0.85 & 0.82 & $1.04^{*}$ \\
\hline Plant/machine operators & 0.62 & 0.60 & 1.03 & 30.60 & 28.59 & 1.07 \\
\hline Professional & 0.19 & 0.20 & $0.97^{*}$ & 0.46 & 0.22 & $2.10^{*}$ \\
\hline Service, shop, \& market & 0.55 & 0.51 & $1.08^{* * *}$ & 25.25 & 16.32 & $1.55^{\star \star \star}$ \\
\hline Technicians \& assoc. prof. & 0.40 & 0.36 & $1.11^{* * *}$ & 4.33 & 3.78 & 1.14 \\
\hline
\end{tabular}

Sources: Frey and Osbourne (2017); PIAAC survey; and IMF staff estimates.

Note: The probability of automation is estimated using an expectation-maximization (EM) algorithm that relates individual characteristics (age, education, training, among other) and job task characteristics to occupational level risk of automation. High automatability is defined as having probability of automation $>=0.7$. Gender ratio $=$ female measure/male measure. Statistical significance level on the ratio refers to the t-test of the differences between male and female means of proportions of workers at high risk of automation. Statistical significance levels: ${ }^{* *} p<0.01 ;{ }^{* *} p<0.05 ;{ }^{*} p<0.1$. 


\section{REFERENCES}

Acemoglu, Daron, and Pascual Restrepo. 2017. "The Race Between Machine and Man: Implications of Technology for Growth, Factor Shares, and Employment." NBER Working Paper No. 22252, National Bureau of Economic Research, Cambridge, MA.

Acemoglu, Daron, and Pascual Restrepo. 2018. "Artificial Intelligence, Automation, and Work." NBER Working Paper No. 24196, National Bureau of Economic Research, Cambridge, MA.

Arntz, Melanie, Terry Gregory, and Ulrich Zierahn. 2017. "Revisiting the risk of automation." Economics Letters 159(C): 157-160.

Autor, David, and David Dorn. 2013. "The Growth of Low-Skill Service Jobs and the Polarization of the US Labor Market." American Economic Review 103 (5): 1553-97.

Autor, David, Frank Levy, and Richard J. Murnane. 2003. "The Skill Content of Recent Technological Change: An Empirical Exploration." The Quarterly Journal of Economics 118 (4): 1279-333.

Bacolod, Marigee P., and Bernardo S. Blum. 2010. "Two Sides of the Same Coin US "Residual" Inequality and the Gender Gap." Journal of Human Resources 45 (1): 197-242.

Beaudry, Paul, and Ethan Lewis. 2014. "Do Male-Female Wage Differentials Reflect Differences in the Return to Skill? Cross-City Evidence from 1980-2000." American Economic Journal: Applied Economics 6(2): 178-194.

Black, Sandra E., and Alexandra Spitz-Oener. 2010. "Explaining Women's Success: Technological Change and the Skill Content of Women's Work." The Review of Economics and Statistics 92 (1): 187-94.

Borghans, Lex, Bas Ter Weel, and Bruce A. Weinberg. "People skills and the labor-market outcomes of underrepresented groups." ILR Review 67.2 (2014): 287-334.

Brussevich, Mariya, Era Dabla-Norris, Christine Kamunge, Pooja Karnane, Salma Khalid and Kalpana Kochhar. 2018. "Gender, Technology and the Future of Work". IMF Staff Discussion Note. Washington DC.

Brynjolfsson, Erik, Tom Mitchell, and Daniel Rock, 2018, "Economic Consequences of Artificial Intelligence and Robotics: What Can Machines Learn and What Does It Mean for Occupations and the Economy?" AEA Papers and Proceedings 108: 43-47.

Cortes, Guido Matias, Nir Jaimovich, and Henry E. Siu. 2018. "The "End of Men" and Rise of Women in High-Skilled Labor Market." NBER Working Paper No. 24274. 
Cuberes, David, Monique Newiak, and Marc Teignier. 2017. "Gender Inequality and Macroeconomic Performance." In, Women, Work, and Economic Growth: Leveling the Playing Field 31-48. Washington, DC: International Monetary Fund.

Das, Mitali, and Benjamin Hilgenstock. 2018."The Exposure to Routinization: Labor Market Implications for Developed and Developing Economies." IMF Working Paper 18/135, International Monetary Fund, Washington, DC.

De La Rica, Sara, and Lucas Gortazar. 2016. "Differences in Job De-Routinization in OECD Countries: Evidence from PIAAC." IZA Discussion Paper No. 9736. Institute for the Study of Labor, Bonn.

Deloitte. 2017. Connecting Small Businesses in the US. Commissioned by Google.

Frey, Carl B., and Michael A. Osborne. 2017. "The Future of Employment: How Susceptible are Jobs to Computerisation?" Technological Forecasting \& Social Change 114: 254-280.

Gelbach, Jonah B. 2012. "When Do Covariates Matter? And Which Ones, and How Much?" Journal of Labor Economics 34 (2): 509-43.

Goos, Maarten, Alan Manning, and Anna Salomons. 2014. "Explaining Job Polarization: RoutineBiased Technological Change and Offshoring." American Economic Review 104 (8): 2509_ 26.

Hawksworth, John, Richard Berriman, and Saloni Goel. 2018. Will Robots Really Steal our Jobs? An International Analysis of the Potential Long-Term Impact of Automation.

PricewaterhouseCoopers.

Hsieh, Chang-Tai, Erik Hurst, Charles I. Jones, and Peter J. Klenow. 2013. "The Allocation of Talent and U.S. Economic Growth." NBER Working Paper No. 18693, National Bureau of Economic Research, Cambridge, MA

Hu, Luojia. 2003. "The Hiring Decisions and Compensation Structures of Large Firms." Industrial and Labor Relations Review 56 (4): 663-81.

Ibrahim, Joseph G. (1990). "Incomplete Data in Generalized Linear Models." Journal of the American Statistical Association 85(411): 765-769.

International Labour Organization. 2016. ASEAN in Transformation: How Technology is Changing Jobs and Enterprises. Geneva.

International Monetary Fund (IMF). 2018. G20 Report on Future of Work: Measurement and Policy Challenges. Washington, DC.

Kleven, Henrik, Camille Landais, Jakob Egholt Sogaard. 2018. "Children and Gender Inequality: Evidence from Denmark." Unpublished manuscript, Princeton University. 
Organisation for Economic Co-operation and Development (OECD). 2016. Proceedings from the Conference on Improving Women's Access to Leadership. Paris, March 8.

Ostry, Jonathan D., Jorge Alvarez, Raphael Espinoza, Chris Papageorgiou. 2018. "Economic Gains from Gender Inclusion: New Mechanisms, New Evidence." IMF Staff Discussion Note. Washington DC.

Weinberg, Bruce A. 2000. "Computer Use and the Demand for Female Workers." Industrial and Labor Relations Review 53 (2) 290-309.

World Economic Forum (WEF). 2016. The Future of Jobs: Employment, Skills and Workforce Strategy for the Fourth Industrial Revolution. Geneva.

World Economic Forum (WEF). 2017a. The Global Gender Gap Report 2017. Geneva. 